\title{
A multi-method approach for identifying meiofaunal trophic connections
}

\author{
D. Leduc ${ }^{1, *}$, P. K. Probert ${ }^{1}$, A. Duncan ${ }^{2}$ \\ ${ }^{1}$ Department of Marine Science, and ${ }^{2}$ Department of Human Nutrition, University of Otago, PO Box 56, Dunedin, \\ New Zealand
}

\begin{abstract}
Meiofauna can play an important role in the energetics of benthic communities, but determining their diet remains problematic due to their small size. In this study, the contribution of primary producers to the diet of meiofauna and to bulk and fine $(<125 \mu \mathrm{m})$ sediment organic matter (SOM) was investigated in Papanui Inlet, southern New Zealand, using stable isotopes $\left(\delta^{13} \mathrm{C}\right.$ and $\delta^{15} \mathrm{~N}$ ) and fatty acid analyses in the field and in a microcosm experiment. Seston did not contribute significantly to SOM of vegetated (seagrass Zostera muelleri) and unvegetated habitats, suggesting limited bentho-pelagic coupling. The contribution of different benthic primary producers to SOM and meiofaunal diet could not be determined accurately based on isotopic signatures alone due to overlapping isotopic signatures. The high content of highly unsaturated fatty acids (HUFAs) of harpacticoid copepods from vegetated and unvegetated sites suggested that their main food item was microphytobenthos (MPB), although bacterial biomarkers were twice as abundant in copepods sampled from the seagrass bed than in copepods sampled from unvegetated sediments. Isotopic and fatty acid analyses showed that the uptake of ${ }^{13} \mathrm{C}$-labeled macroalgal (Enteromorpha sp.) detritus by harpacticoid copepods in the microcosm experiment was minimal. Nematode diet could not be assessed with certainty, but seagrass detritus and MPB are likely to represent significant food sources at the vegetated and unvegetated sites, respectively, based on the fatty-acid profile of fine SOM. This combined approach (i.e. isotopic and fatty acid analyses, field sampling and microcosms), and analysis of bulk SOM, fine SOM, and aged seagrass detritus helped circumvent limitations associated with the individual methods. The combination of approaches was still insufficient to quantify the contribution of different primary producers to meiofaunal diet, however, highlighting the difficulties associated with the study of meiofaunal trophic connections in coastal systems.
\end{abstract}

KEY WORDS: Parastenhelia megarostrum • Feeding ecology · Intertidal

\section{INTRODUCTION}

Despite their low biomass, meiofauna can play an important role in the carbon flux of benthic communities due to their high turnover rate (Kuipers et al. 1981). Nematodes, for example, can ingest twice their body carbon each day (Heip et al. 1985), and grazing by meiofauna may control microalgal biomass (Blanchard 1991, Montagna et al. 1995). Harpacticoid copepods also constitute an important link between primary producers and higher trophic levels (see review by Coull 1999). Understanding the role of meiofauna in benthic carbon flux requires detailed knowledge of their diet. Our understanding of meiofaunal trophic relationships in coastal habitats is, however, still fragmentary because of the small size of meiofaunal organisms and the many food sources available.

The trophic ecology of nematodes (typically the dominant meiofaunal taxon) is often interpreted using the feeding group classification based on buccal cavity morphology (Wieser 1953), or modified versions thereof (e.g. Romeyn \& Bouwman 1983). Such classification schemes do not, however, always accurately represent the feeding habits of nematodes (Moens \& 
Vincx 1997). The use of stable isotopes as tracers of organic matter flows in benthic food webs has shed light on the diet of nematodes and harpacticoid copepods in a variety of shallow benthic habitats (e.g. Couch 1989, Middelburg et al. 2000, Moens et al. 2005). Few studies have determined the isotopic signature of nematodes and harpacticoid copepods in seagrass meadows (e.g. Vizzini \& Mazzola 2003), which contrasts with the numerous stable isotope studies of macrofauna of seagrass beds (see review by Lepoint et al. 2004).

Carbon stable isotopes can be particularly useful for the study of food webs of seagrass communities due to the often elevated $\delta^{13} \mathrm{C}$ signature of seagrass tissue relative to other primary producers (Hemminga \& Mateo 1996). The difference in $\delta^{13} \mathrm{C}$ signatures between consumers and food sources is usually small $(<1 \%$ o), which allows for accurate determination of diet (McCutchan et al. 2003). Nitrogen isotopes are often used as an additional tracer when multiple food sources are present. Consumer $\delta^{15} \mathrm{~N}$ signatures are typically enriched relative to their diet by about $3 \%$, which makes nitrogen isotopes useful for the identification of both food resource(s) and trophic level (Post 2002).

The use of stable isotopes in coastal food-web studies has limitations. For example, different primary producers can have overlapping isotopic signatures (Mutchler et al. 2004), which may hinder the interpretation of food-web relationships. Accurate determination of benthic microalgal isotopic signatures can be hampered by bias associated with sampling methods (Cook et al. 2004) and high variability in isotopic signatures over short spatial scales (Leduc et al. 2006). Microphytobenthos (MPB) is often not sampled in food-web studies because dense mats of microalgae are not found (e.g. Kharlamenko et al. 2001). Since the contribution of a food source to consumers may relate more to its quality (i.e. palatability) than to its quantity (Tenore et al. 1982), the importance of MPB in seagrass food webs may have been underestimated. This could be particularly true for meiofauna because they may (due to their small size) be able to exert greater discrimination between food sources than macrofauna.

The importance of macrophytes to the diet of benthic consumers is not always easy to establish conclusively in stable isotope studies due to the often high intraand inter-specific variability in $\delta^{13} \mathrm{C}$ signatures (e.g. Vizzini \& Mazzola 2003). Stable isotope enrichment experiments can help better characterize the contribution of a food source to consumers, but this approach is seldom used to investigate the fate of macrophyte detritus in benthic food webs (Rossi 2007). In contrast, several stable-isotope enrichment studies have investigated the importance of microalgae in the diet of meiofauna (e.g. Carman \& Fry 2002, Moens et al. 2007).

The contribution of some food sources, such as bac- teria, cannot be evaluated using the analysis of bulk stable isotopic signatures. This shortcoming has led some researchers to use fatty acid (FA) biomarkers in addition to stable isotopes in food-web studies (Kharlamenko et al. 2001, Nyssen et al. 2005, Jaschinski et al. 2008), but few studies to date have combined both techniques to investigate marine meiofaunal trophic connections (Leduc 2009). FAs are useful for the study of coastal food webs because they provide specific markers for organisms such as bacteria (e.g. 15:0, 17:0, and 18:1n7; Volkman et al. 1980, Findlay et al. 1990), diatoms (e.g. 20:5n3; Ackman et al. 1968), and vascular plants (e.g. 18:3n3; Kharlamenko et al. 2001). The FA composition of consumers reflects the FA composition of their diet (Parrish et al. 2000), but the relative amounts of FA biomarkers in animal tissues can vary due to environmental variables (e.g. temperature; Pernet et al. 2007) and internal metabolism. Several crustacean taxa, such as harpacticoid copepods (Nanton \& Castell 1999) and shrimps (Kanazawa et al. 1979), can biosynthesize significant amounts of highly unsaturated FAs (HUFAs, defined as FAs having carbon chain length $\geq \mathrm{C}_{20}$ and with $\geq 3$ double bonds) such as 20:5n3 and 22:6n3. The information gained from the FA profiles of consumers from the field is therefore mostly qualitative.

FA biomarkers can also be used to determine the contribution of different organic matter sources to sediment organic matter (SOM) (Meziane \& Tsuchiya 2000). The FA composition of SOM can be compared to the FA composition of primary producers using multivariate statistics because the effect of metabolism does not need to be taken into account (although some researchers compare consumers and food sources; see Jaschinski et al. 2008), thus lowering the need to rely on specific FA biomarkers. The effect of microbial decomposition on the FA composition of primary producers should be considered, however. The FA profile of live seagrass blades, for example, differs significantly from seagrass detritus due to the loss of some FAs during decomposition and to the presence of bacterial FAs (Kharlamenko et al. 2001).

Meiofauna may selectively assimilate different components of SOM (e.g. Couch 1989, Moens et al. 2007). Food selectivity by nematodes may depend largely on particle size (Moens \& Vincx 1997), but most studies investigating meiofauna diet analyze only bulk SOM rather than different size fractions (Couch 1989). A better characterization of fine (i.e. $<125 \mu \mathrm{m}$ ) SOM through stable isotope and FA analyses is likely to lead to better interpretations of food-web relationships, since fine SOM represents the most likely food source for meiofauna. Such analyses may also be useful in determining the degree of benthopelagic coupling associated with the enhanced settlement and retention of fine sus- 
pended particulate organic matter known to occur in some seagrass beds (Papadimitriou et al. 2005).

The small size (and associated technical challenges) of meiofaunal organisms is usually considered a disadvantage in ecological studies. That meiofauna spend their entire life cycles in a restricted area of sediments, however, makes them more suited to the study of ecological processes occurring over small (10 to $100 \mathrm{~m}$ ) spatial scales than larger, more mobile animals. Researchers have studied the export of seagrass material to invertebrates living outside seagrass beds on a km scale (e.g. Hyndes \& Lavery 2005), but studies comparing the diet of invertebrates living inside seagrass beds and immediately adjoining unvegetated sediments are difficult to find. The effect of seagrass on benthic trophic pathways may be better understood by comparing the diet of animals in nearby locations differing mainly in the presence or absence of seagrass vegetation. Comparing the isotopic signatures of organisms over small spatial scales is also more likely to yield meaningful insights about potential foodsource differences associated with the presence of seagrass cover than comparing organisms living far apart (Boschker et al. 2000).

The aims of the present study were to (1) test for differences in the contribution of primary producers to SOM and meiofaunal diet inside and outside an intertidal Zostera muelleri meadow, (2) compare the composition of bulk and fine $(<125 \mu \mathrm{m})$ SOM in vegetated and unvegetated habitats, (3) test whether meiofauna feed preferentially on fine SOM as opposed to bulk SOM, (4) evaluate the importance of macroalgal detritus to the nutrition of harpacticoid copepods in a feeding experiment, and (5) test for differences in the FA composition of fresh and aged seagrass detritus under controlled conditions. The dietary contribution of primary producers was estimated using dual stable isotope analyses $\left(\delta^{13} \mathrm{C}\right.$ and $\left.\delta^{15} \mathrm{~N}\right)$ and FA biomarkers (SOM and harpacticoid copepods only).

\section{MATERIALS AND METHODS}

Study area. The study was carried out in Papanui Inlet, southern New Zealand (Fig. 1), an unpolluted sheltered inlet with an area of $3.5 \mathrm{~km}^{2}$. Tides are semidiurnal with a mean tidal range of $1.15 \mathrm{~m}$ (Albrecht \& Vennell 2007). Most of the inlet is exposed at low tide and consists of a patchwork of unvegetated sediments and Zostera muelleri beds. Freshwater input is minimal.

Three $10 \times 10 \mathrm{~m}$ sampling sites were used. Site 1 $\left(45^{\circ} 50^{\prime} 53.1^{\prime \prime} \mathrm{S}, 170^{\circ} 42^{\prime} 40.9^{\prime \prime} \mathrm{E}\right)$ consisted of unvegetated sandy sediments, Site 2 (45 50'46.8" S, $\left.170^{\circ} 42^{\prime} 35.1^{\prime \prime} \mathrm{E}\right)$ was located within a sparsely vegetated (1250 shoots $\mathrm{m}^{-2}$ ) Zostera muelleri bed, and Site 3 $\left(45^{\circ} 50^{\prime} 48.1^{\prime \prime} \mathrm{S}, 170^{\circ} 42^{\prime} 35.7^{\prime \prime} \mathrm{E}\right)$ was located within a densely vegetated (8920 shoots $\left.\mathrm{m}^{-2}\right) \quad Z$. muelleri meadow. The sites were within $150 \mathrm{~m}$ of each other, and situated at least $30 \mathrm{~m}$ from the edge of the $Z$. muelleri meadow.

Sample collection and processing. Macrophytes were sampled in January 2006 at low tide. Zostera muelleri blades were sampled from Sites 2 and 3. Careful examination of the blades under dissecting and compound microscopes on several occasions during the year revealed the near-absence of epiphytes, which were therefore not sampled. The dominant macroalgal species (Ulva sp., Enteromorpha sp., and Polysiphonia sp.) found within or in close proximity $(\leq 50 \mathrm{~m})$ to the sites were also sampled. All macrophyte samples were washed several times with distilled water and inspected under the compound microscope to ensure that no debris was present. Samples for isotopic analysis were dried at $60^{\circ} \mathrm{C}$ for $2 \mathrm{~d}$, homogenized using a mortar and pestle, and kept frozen until analysis. Triplicate samples consisting of 1 blade or thallus each were taken for each macrophyte for stable isotope and FA analyses.
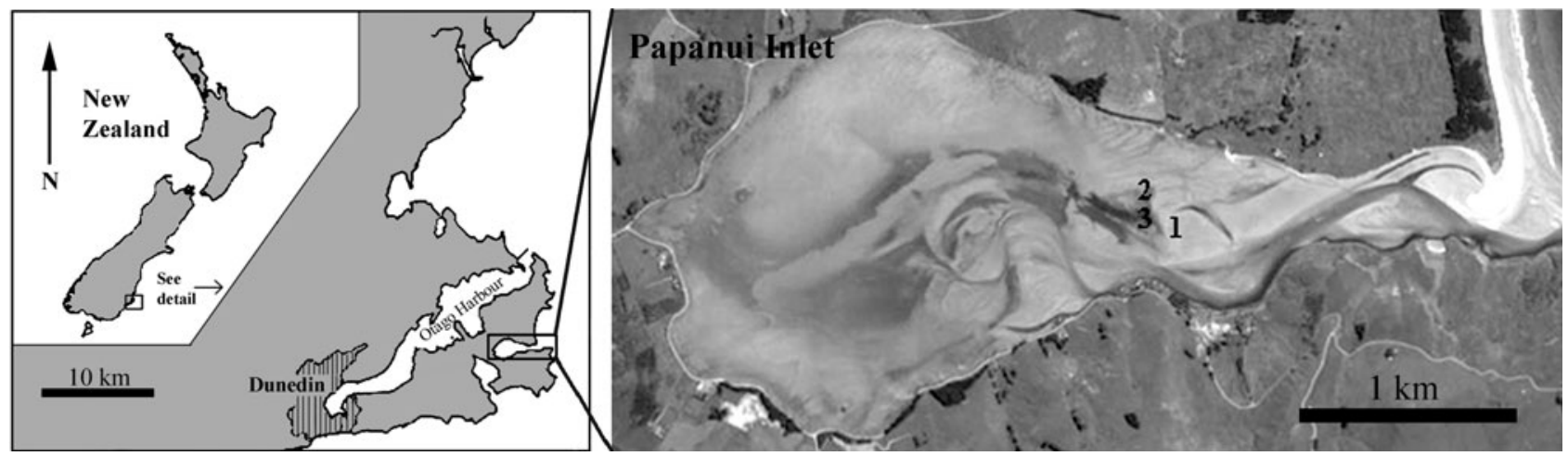

Fig. 1. New Zealand and Papanui Inlet. Beds of the seagrass Zostera muelleri are visible as dark areas within the inlet. Site 1: unvegetated sediments, 2: sparse $Z$. muelleri meadow, and 3: dense $Z$. muelleri meadow 
MPB was sampled as described by Leduc et al. (2006) on several occasions when dense mats were visible on the sediment surface (June 2005, January 2006, and January 2007). The surface of colored (orange or green) sediment was scraped with a metal spatula. Microalgae were separated by vigorous shaking of the sample with filtered (GF/F filter, $0.7 \mu \mathrm{m}$ retention size) seawater in the laboratory and filtered through a $63 \mu \mathrm{m}$ sieve to remove large particles and meiofauna. The presence or absence of contaminants was verified by observing several aliquots of the sample under a compound microscope (samples containing contaminants were discarded). Samples for isotopic analysis were filtered through a pre-combusted Whatman fiberglass $\mathrm{GF} / \mathrm{F}$ filter $(0.7 \mu \mathrm{m}$ retention size $)$, dried at $60^{\circ} \mathrm{C}$ for $1 \mathrm{~h}$, left for $24 \mathrm{~h}$ in an $\mathrm{HCl}$ atmosphere to remove carbonates, re-dried, and kept frozen. Triplicate samples were obtained at each sampling event for stable isotope and FA analyses. The amount of material collected in January 2006 was insufficient for FA analysis.

Samples for the isotopic and FA analysis of SOM were obtained in January 2006 from all sites ( $\mathrm{n}=3$ for each site). SOM samples were obtained by scraping the top $2 \mathrm{~cm}$ of sediments and did not include large $(\geq 1 \mathrm{~cm})$ pieces of macrophytes that were sometimes present on the sediment surface. SOM samples were separated into bulk and fine $(<125 \mu \mathrm{m})$ fractions in the laboratory on the day of sampling. The small fraction was obtained by sieving a subsample through a $125 \mu \mathrm{m}$ sieve. The resulting sample was centrifuged at $4000 \mathrm{rpm}(\sim 1800 \times g)$ for $3 \mathrm{~min}$ and the supernatant removed. Samples for isotopic analysis were dried at $60^{\circ} \mathrm{C}$ for $2 \mathrm{~d}$ and homogenized using a mortar and pestle. A small quantity of each sample ( 40 mg) was left in an $\mathrm{HCl}$ atmosphere for $24 \mathrm{~h}$ to remove carbonates (Hedges \& Stern 1984). Samples were re-dried and kept frozen until analysis.

Nematodes were sampled for isotopic analysis in January 2006 at all sites. The top $2 \mathrm{~cm}$ of sediments was scraped with a small shovel, transferred into 11 plastic bags, and kept frozen. Samples were later thawed, and meiofauna was extracted by repeated decantation over a $125 \mu \mathrm{m}$ sieve. Most of the remaining debris was removed using the Ludox flotation technique (Somerfield \& Warwick 1996). Extraction with Ludox has been found to have no significant effect on the isotopic signatures of nematodes (Moens et al. 2002, 2007). The resulting samples were washed several times with distilled water and transferred into a Petri dish. Nematodes were picked out individually using a fine needle, washed with distilled water, dried at $60^{\circ} \mathrm{C}$ for $24 \mathrm{~h}$, transferred into aluminum cups, and kept in a dehydrator until analysis. Three replicates, each consisting of several hundred individuals, were obtained.
Samples for the isotopic analysis of harpacticoid copepods were obtained in January 2006 from all sites. Samples for FA analysis were taken in January 2007 from Sites 1 and 3. Harpacticoid copepods at Site 3 were sampled from small $\left(0.5\right.$ to $\left.2.0 \mathrm{~m}^{2}\right)$ unvegetated patches within the Zostera muelleri bed because insufficient material was obtained from vegetated sediments. Copepods were sampled by transferring about 11 of surface sediment into plastic bags. Copepods were extracted live by repeated decantation over a $125 \mu \mathrm{m}$ sieve, and transferred into Petri dishes. This mesh size was used to minimize the amount of debris and facilitate extraction, and only retained adults and late-stage copepodites (and not nauplii). The Petri dishes were placed under natural light and copepods were left to aggregate on 1 side of the dish. Copepods (along with a small quantity of debris) were transferred into a clean Petri dish containing filtered seawater with a transfer pipette. The procedure was repeated several times over a period of $24 \mathrm{~h}$ (allowing copepods to clear gut contents) until no debris was present in the sample. Copepod samples consisted mostly of Parastenhelia megarostrum, the most common species in New Zealand sandflats (Wells et al. 1982). Copepods were washed thoroughly with distilled water, and samples for isotopic analysis were dried at $60^{\circ} \mathrm{C}$ for $24 \mathrm{~h}$. Samples were acidified by placing a small amount (1 to $2 \mathrm{mg}$ ) of ground tissue in an $\mathrm{HCl}$ atmosphere for $24 \mathrm{~h}$ (Hedges \& Stern 1984). Three replicates (each consisting of several hundred individuals) from each site were obtained.

All samples for isotopic analysis contained a minimum of about $70 \mu \mathrm{g} \mathrm{C}$ and $20 \mu \mathrm{g} \mathrm{N}$. Samples for FA analysis (primary producers, SOM, and harpacticoid copepods) were processed as for isotope samples, but were freeze-dried instead of air-dried, and kept at $-80^{\circ} \mathrm{C}$ until analysis. Isotopic signatures of seston obtained previously in the region were used (Leduc et al. 2006). Earlier research suggests that the range of seasonal and inter-annual variability in seston isotopic signatures near the Otago coast is limited (R. Van Hale pers. comm.). Samples of macrophytes, nematodes, and harpacticoid copepods were also obtained in June 2005 for stable isotope analysis, but a significant proportion of the samples were lost due to instrument malfunction. The available data are presented in the tables but were not included in the analysis and discussion.

Feeding experiment. Enteromorpha sp. thalli were obtained in November 2006 from Papanui Inlet, Otago Peninsula. Enteromorpha sp. is seasonally abundant in Papanui Inlet (D. Leduc pers. obs.) and may constitute an important food source to benthic invertebrates. Isotopic labeling of Enteromorpha sp. in the laboratory largely followed the procedure used by Boschker et al. (2000) for the labeling of Zostera marina. Labeling 
medium was prepared by adding $0.65 \mathrm{~g}$ of $\mathrm{NaHCO}_{3}$ $\left({ }^{13} \mathrm{C}, 99 \%\right.$ Novachem) to 201 of filtered seawater. Enteromorpha sp. thalli were labeled in a plastic tank containing the labeling medium for $5 \mathrm{~h}$ under artificial light $\left(270 \mu \mathrm{E} \mathrm{m}^{-2} \mathrm{~s}^{-1}\right)$. After labeling, Enteromorpha sp. thalli were transferred to plastic containers with flowing filtered seawater for $16 \mathrm{~h}$ to allow the label to distribute in the plants. Thalli were then washed repeatedly in distilled water, freeze-dried, ground to a particle size $<125 \mu \mathrm{m}$, and kept frozen at $-80^{\circ} \mathrm{C}$.

Microcosms were established in square plastic boxes $(34 \times 34 \mathrm{~cm}, 20 \mathrm{~cm}$ deep). Overflow pipes (17 cm high) in the center of the microcosms were covered with $45 \mu \mathrm{m}$ mesh to prevent loss of meiofauna. On 21 January 2007 , the top $2 \mathrm{~cm}$ of intertidal unvegetated sediments at Site 1 was transferred directly into the microcosms ( $n=8$ ) using a flat aluminum shovel, taking care to minimize disturbance to the sediments. Harpacticoid copepod samples $(n=4)$ for isotopic and FA analyses were obtained by transferring surface sediments into 11 plastic bags. Five haphazardly allocated cores (2.6 cm diameter, $2 \mathrm{~cm}$ depth) were taken and fixed in $5 \%$ formalin for estimation of meiofaunal and harpacticoid copepod abundance and biomass. Samples were extracted using the Ludox flotation technique and biomass estimated using video image analysis (Grove et al. 2006). The microcosms were immediately brought to the Portobello Marine Laboratory and each microcosm was provided with 2 seawater inflows at opposite corners and left to settle. The following day, $2 \mathrm{~g}$ dry weight (DW) of Enteromorpha sp. material was added to 4 randomly chosen microcosms and distributed evenly on the surface of the sediments. The remaining 4 microcosms were left as controls. All the microcosms were put under a $16 \mathrm{~h}$ light:8 h dark cycle for $7 \mathrm{~d}$. This duration was considered adequate as (1) meiofauna have a fast biomass turnover rate and (2) an extended experiment could bias the results due to the artificial conditions in the microcosms. Light intensity was $270 \mu \mathrm{E} \mathrm{m} \mathrm{m}^{-2} \mathrm{~s}^{-1}$, and seawater temperature was $15 \pm$ $1^{\circ} \mathrm{C}$. The conditions provided during the experiment allowed the survival and growth of naturally occurring benthic microalgae, as ascertained by the observations of several sediment aliquots during the experiment. The isotopic and FA composition of harpacticoid copepods was measured at the beginning of the experiment from the field samples and after the experiment from the treatment and control microcosms. Harpacticoid samples were extracted as described above (see 'Sample collection and processing').

Seagrass detritus experiment. The FA composition of seagrass detritus can change during decomposition (Tenore et al. 1984), so the characterization of FA profiles of decomposing material is necessary to accurately determine their contribution to SOM pools.
Fresh seagrass blades obtained from Site 3 (January 2006) were rinsed several times in distilled water, freeze-dried, and ground to a particle size between 45 and $250 \mu \mathrm{m}$. We added $2 \mathrm{~g}$ of detritus to $100 \mathrm{ml}$ of $\mathrm{f} / 2$ medium in conical flasks $(\mathrm{n}=4)$, which were left in the dark at $15^{\circ} \mathrm{C}$ on a shaker table for $28 \mathrm{~d}$ (Tenore et al. 1977). Each flask was inoculated at the beginning of the experiment with $2 \mathrm{ml}$ of sand-filtered seawater to provide microbiota. Each week, an additional $10 \mathrm{ml}$ of $\mathrm{f} / 2$ medium was added to the flasks to ensure adequate nutrient supply (Tenore et al. 1977). After $4 \mathrm{wk}$, the contents of the flasks were centrifuged, the supernatant decanted, and the detritus kept frozen at $-80^{\circ} \mathrm{C}$ until analysis.

Stable isotope and FA analysis. Isotopic analyses were conducted at Iso-trace NZ (Dunedin, New Zealand) on a Europa 20-20 Update stable isotope mass spectrometer (Europa Scientific) interfaced to a Carlo Erba analyzer (NA1500) in continuous-flow mode (precision: $0.2 \%$ ). Analysis was calibrated to EDTA laboratory standard reference (Elemental Microanalysis) and standardized against international standards (IAEACH-6 for carbon, IAEAN1 and IAEAN2 for nitrogen). Results are expressed relative to standards (Vienna PDB for carbon and atmospheric N for nitrogen) in standard delta notation according to the formula:

$$
\delta^{13} \mathrm{C} \text { or } \delta^{15} \mathrm{~N}=\left[\left(R_{\mathrm{SAMPLE}} / R_{\mathrm{STANDARD}}\right)-1\right] \times 10^{3} \%
$$

where $R$ is the ratio of ${ }^{13} \mathrm{C}:{ }^{12} \mathrm{C}$ or ${ }^{15} \mathrm{~N}:{ }^{14} \mathrm{~N}$.

Lipids were extracted using a method modified from Bligh \& Dyer (1959). Lipids were extracted using chloroform:methanol $(2: 1 \mathrm{v} / \mathrm{v})$. The lipid fraction was treated with sulfuric acid (AnalaR, BDH Chemicals) in methanol solution and underwent acid-catalyzed transesterification at $80^{\circ} \mathrm{C}$ for $12 \mathrm{~h}$. FA esters were extracted in hexane:water. The hexane-containing layer was removed, dried using $\mathrm{N}_{2}$ gas, and reconstituted in $100 \mu$ l hexane. FA composition was determined by gas chromatography on a 5890 GC equipped with an HP7673 autosampler (Hewlett Packard). FA methyl esters (FAMEs) were separated on a DB225 capillary column, $30 \mathrm{~m} \times 0.53 \mathrm{~mm}$ ID, $0.25 \mu \mathrm{m}$ film (Agilent Technologies). The column oven temperature was increased from 180 to $200^{\circ} \mathrm{C}$ over $50 \mathrm{~min}$. FA peaks were identified by retention time matching with a composite standard made from commercially available methyl esters (NUCheck Prep and Sigma) and additional specific standards (Sigma-Aldrich: PUFA No. 1 and Supelco 37 component FAME mix). Peak areas were calculated and reported as percentage of total FAs. FAs were expressed as the ratio of the number of carbon atoms to the number of double bonds. Double bond position (n) is numbered from the methyl end of the FA. 
Data analysis. Statistical analyses (ANOVA and Student's $t$-test) were conducted using Minitab 14 software. All data were checked for and met the normality and variance homogeneity requirements for parametric analyses. FA composition of SOM from the 3 sites was compared by constructing Euclidean similarity matrices from untransformed data in PRIMER (Clarke \& Gorley 2006). The use of Euclidean similarity matrices is preferable to Bray-Curtis similarity matrices because FA data are continuous. The data were not transformed as this would otherwise inappropriately weight FAs present in low proportions. Differences in FA composition between sites and size fractions were tested using 2-way analysis of similarities (ANOSIM).

${ }^{13} \mathrm{C}$ label incorporation ( $L I$, expressed in $\mu g{ }^{13} \mathrm{C}$ ) by harpacticoid copepods at the end of the experiment was calculated as the product of excess ${ }^{13} \mathrm{C}(E)$ and biomass (Moens et al. 2002). Excess ${ }^{13} \mathrm{C}$ is the difference between the fraction ${ }^{13} \mathrm{C}(F)$ of control and sample, i.e.:

$$
E=F_{\text {sample }}-F_{\text {control }}
$$

where $F={ }^{13} \mathrm{C} /\left({ }^{13} \mathrm{C}+{ }^{12} \mathrm{C}\right)=R /(R+1)$. The carbon isotope ratio $(R)$ was derived from the measured $\delta^{13} \mathrm{C}$ values as $R=\left(\delta^{13} \mathrm{C} / 1000+1\right) \times R_{\mathrm{VPDB}}$, where $R_{\mathrm{VPDB}}=$ $0.0112372=$ the carbon isotope ratio of the reference material (Vienna PDB) (Fry 2006). Label intake was translated into detritus incorporation by harpacticoid copepods by using the following equations:

$$
\begin{gathered}
C I=L I \times 100 / \text { atom } \%{ }^{13} \mathrm{C}_{\text {detritus }} \\
D I=C I \times 100 / \% \mathrm{C}_{\text {detritus }}
\end{gathered}
$$

where $C I=$ carbon intake $(\mu \mathrm{C})$, atom $\%{ }^{13} \mathrm{C}=100 \times \mathrm{F}$ (Fry 2006), and $D I=$ detritus incorporation $(\mu \mathrm{g} D \mathrm{DW})$, and $D I$ was translated into weight-specific detritus incorporation rates ( $\mu \mathrm{g} \mathrm{DW}_{\text {detritus }} \mathrm{mg} \mathrm{DW}^{-1}$ consumer $\mathrm{d}^{-1}$ ) by dividing DI by the biomass (mg DW) of harpacticoid copepods in the microcosms and by the number of days (7) the experiment lasted.

The contribution of Enteromorpha sp. detritus to the carbon demand of copepods was estimated by using the equation:

$$
C D=(P / 52) / C C E
$$

where $C D=$ carbon demand (in $\mathrm{g} C$ microcosm ${ }^{-1} \mathrm{wk}^{-1}$ ), $P=$ gross production $\left(\mathrm{g} \mathrm{C}\right.$ microcosm $\left.{ }^{-1} \mathrm{yr}^{-1}\right)$, and $C C E=$ carbon conversion efficiency (Danovaro et al. 2002). $C C E$ was not taken into account in the present study because only assimilated $\mathrm{C}$ is measured in stable isotope determinations. Annual production was estimated by multiplying the biomass of each species ( $\mathrm{g} \mathrm{C}$ micro$\operatorname{cosm}^{-1}$ ) with published annual production:biomass $(P: B)$ ratios. A $P: B$ ratio of 15 has previously been estimated for Parastenhelia megarostrum (Hicks 1984). The proportion of $C D$ met by assimilation of Enteromorpha sp. was calculated by dividing $C I$ by $C D$.

\section{RESULTS}

\section{Stable isotopic signatures and C:N ratios}

The mean $\delta^{13} \mathrm{C}$ signature of primary producers at Papanui Inlet ranged from -18.6 (Enteromorpha sp.) to $-8.9 \%$ (MPB) (Table 1). The $\delta^{13} \mathrm{C}$ values of Zostera muelleri were elevated $(-12.1$ to $-10.4 \%$ ) whereas macroalgal values tended to be more negative $(-18.6$ to $-12.2 \%$ ). MPB $\delta^{13} \mathrm{C}$ signatures $(-15.2$ to $-8.9 \%$ ) overlapped with both $Z$. muelleri and macroalgal signatures. The range of primary producer $\delta^{15} \mathrm{~N}$ values was limited, with mean values ranging from 6.4 (MPB) to $7.8 \%$ (Polysiphonia sp.). The C:N ratio of primary producers ranged from 8 (Polysiphonia sp.) to 27 (Ulva sp.).

The isotopic signatures of SOM had limited variation between sites and size fractions with mean $\delta^{13} \mathrm{C}$ and $\delta^{15} \mathrm{~N}$ values ranging from -13.9 to $-11.1 \%$ and from 6.1 to $6.7 \%$, respectively. Bulk SOM had significantly lower values of $\delta^{13} \mathrm{C}$ at Site 2 than at the other 2 sites but the difference was small (0.9 to $1.4 \%$, ANOVA and Tukey's post hoc test, $\mathrm{p}<0.05)$. The $\delta^{13} \mathrm{C}$ signature of fine $(<125 \mu \mathrm{m})$ SOM differed significantly between sites, with Site $1>$ Site $2>$ Site $3(p<0.05)$. Values of $\delta^{15} \mathrm{~N}$ of fine SOM at Site 3 were also significantly lower than at the other 2 sites $(p<0.05)$, but the difference was slight $(0.5 \%)$. The $\delta^{15} \mathrm{~N}$ signature of bulk SOM could not be determined due to the low nitrogen content of the samples. The C:N ratio of SOM ranged from 11 (bulk SOM at Site 2) to 15 (bulk SOM at Site 3).

Nematode and harpacticoid copepod $\delta^{13} \mathrm{C}$ signatures were relatively enriched in ${ }^{13} \mathrm{C}$ and were similar to Zostera muelleri, MPB, and macroalgal signatures (Fig. 2). Nematode $\delta^{13} \mathrm{C}$ and $\delta^{15} \mathrm{~N}$ signatures were significantly more depleted at Site 3 than at Sites 1 and 2 (ANOVA and Tukey's post hoc test, $\mathrm{p}<0.05$,), and followed the pattern observed in fine-SOM isotopic signatures. Nematode $\delta^{15} \mathrm{~N}$ signatures were 1.3 to $3.6 \%$ higher than their potential food sources. Harpacticoid copepod samples were predominantly Parastenhelia megarostrum at all sites (see 'Feeding experiment and harpacticoid copepod FA profiles'). Their $\delta^{13} \mathrm{C}$ and $\delta^{15} \mathrm{~N}$ signatures were not significantly different between sites ( $p>0.05)$, which was due, at least in part, to the high variability in isotopic signatures observed at Site 3. Copepod $\delta^{15} \mathrm{~N}$ signatures were enriched by 0.7 to $2.3 \%$ relative to their potential food sources.

\section{Primary producers and SOM FA profiles}

The FA profiles of all primary producers were characterized by high levels of 16:0 (Table 2). The most common FAs in Zostera muelleri blades were 
Table 1. Isotopic analysis of primary producers, sediment organic matter (SOM), meiofauna, and macrofauna at Sites 1 (unvegetated sediment), 2 (sparse Zostera muelleri), and 3 (dense Z. muelleri) at Papanui Inlet (values are mean $\pm \mathrm{SD}, \mathrm{n}=3$ ). $\mathrm{MPB}=$ microphytobenthos, na $=$ not applicable, nd $=$ no data. Superscripted letters denote that values of $\delta^{13} \mathrm{C}$ and $\delta^{15} \mathrm{~N}$ for SOM and consumers at each sampling time are not statistically different between sites ( $t$-test or 1 -way ANOVA, $<<0.05$ )

\begin{tabular}{|c|c|c|c|c|c|c|c|}
\hline & Site & Date (mm/yy) & $\delta^{13} \mathrm{C}$ & $\delta^{15} \mathrm{~N}$ & $\% \mathrm{C}$ & $\% \mathrm{~N}$ & $\mathrm{C}: \mathrm{N}$ \\
\hline \multicolumn{8}{|l|}{ Primary producers } \\
\hline Z. muelleri & 3 & 06/05 & $-12.1 \pm 0.2$ & nd & nd & nd & nd \\
\hline Z. muelleri & 2 & $01 / 06$ & $-10.4 \pm 0.5$ & $7.3 \pm 0.2$ & $42.8 \pm 2.6$ & $2.5 \pm 0.2$ & $20.1 \pm 0.2$ \\
\hline Z. muelleri & 3 & $01 / 06$ & $-11.7 \pm 0.4$ & $7.1 \pm 0.3$ & $40.8 \pm 3.7$ & $2.0 \pm 0.2$ & $23.6 \pm 0.3$ \\
\hline Ulva sp. & 2,3 & 06/05 & $-12.2 \pm 0.1$ & nd & nd & nd & nd \\
\hline Ulva sp. & 2,3 & $01 / 06$ & $-16.2 \pm 1.0$ & $7.1 \pm 0.1$ & $29.9 \pm 3.2$ & $1.3 \pm 0.2$ & $26.8 \pm 0.6$ \\
\hline Enteromorpha sp. & 1,2 & $01 / 06$ & $-18.6 \pm 0.2$ & $7.2 \pm 0.2$ & $31.3 \pm 0.3$ & $1.9 \pm 0.0$ & $19.5 \pm 0.5$ \\
\hline Polysiphonia sp. & 3 & 06/05 & $-15.7 \pm 0.1$ & nd & nd & nd & nd \\
\hline Polysiphonia sp. & 3 & $01 / 06$ & $-14.7 \pm 0.2$ & $7.8 \pm 0.2$ & $34.8 \pm 0.2$ & $5.1 \pm 0.1$ & $8.0 \pm 0.2$ \\
\hline $\begin{array}{l}\text { MPB (dinoflagellates } \\
+ \text { diatoms) }\end{array}$ & 1,2 & $06 / 05$ & $-8.9 \pm 0.1$ & $6.6 \pm 0.3$ & nd & nd & $11.3 \pm 0.5$ \\
\hline MPB (cyanobacteria) & 2 & 06/05 & $-15.2 \pm 0.1$ & $7.4 \pm 0.3$ & nd & nd & $6.0 \pm 0.0$ \\
\hline $\begin{array}{l}\text { MPB (euglenoids } \\
+ \text { diatoms) }\end{array}$ & 1,2 & 01/06 & $-15.1 \pm 0.7$ & $6.4 \pm 0.1$ & nd & nd & $10.1 \pm 1.2$ \\
\hline MPB (cyanobacteria) & 3 & $01 / 07$ & $-13.8 \pm 0.1$ & $7.3 \pm 0.3$ & nd & nd & $9.5 \pm 0.1$ \\
\hline Seston $^{*}$ & na & 03/03 & $-22.3 \pm 0.1$ & $6.4 \pm 0.2$ & nd & nd & nd \\
\hline \multicolumn{8}{|l|}{ SOM } \\
\hline Bulk & 1 & $01 / 06$ & $-11.6 \pm 0.5^{\mathrm{a}}$ & nd & $0.1 \pm 0.0$ & $<0.1$ & $13.8 \pm 0.4$ \\
\hline Bulk & 2 & $01 / 06$ & $-12.5 \pm 0.4^{\mathrm{b}}$ & nd & $0.2 \pm 0.0$ & $<0.1$ & $11.3 \pm 0.4$ \\
\hline Bulk & 3 & 01/06 & $-11.1 \pm 0.2^{\mathrm{a}}$ & nd & $0.7 \pm 0.0$ & $<0.1$ & $15.3 \pm 0.5$ \\
\hline Fine $(<125 \mu \mathrm{m})$ & 1 & $01 / 06$ & $-11.2 \pm 0.2^{\mathrm{a}}$ & $6.7 \pm 0.3^{\mathrm{a}}$ & $3.0 \pm 0.1$ & $0.2 \pm 0.0$ & $14.7 \pm 0.3$ \\
\hline Fine $(<125 \mu \mathrm{m})$ & 2 & $01 / 06$ & $-12.3 \pm 0.1^{\mathrm{b}}$ & $6.6 \pm 0.3^{a}$ & $3.1 \pm 0.3$ & $0.2 \pm 0.0$ & $13.0 \pm 0.5$ \\
\hline Fine $(<125 \mu \mathrm{m})$ & 3 & $01 / 06$ & $-13.9 \pm 0.1^{\mathrm{c}}$ & $6.1 \pm 0.0^{\mathrm{b}}$ & $2.8 \pm 0.5$ & $0.2 \pm 0.0$ & $11.9 \pm 0.2$ \\
\hline \multicolumn{8}{|l|}{ Meiofauna } \\
\hline Nematodes & 1 & 06/05 & $-12.4 \pm 0.4^{\mathrm{a}}$ & $10.3 \pm 0.6$ & $45.6 \pm 0.3$ & $10.1 \pm 0.2$ & $5.4 \pm 0.2$ \\
\hline Nematodes & 3 & 06/05 & $-14.7 \pm 0.2^{\mathrm{b}}$ & $9.9 \pm 0.8$ & $46.7 \pm 0.7$ & $10.7 \pm 0.3$ & $5.3 \pm 0.4$ \\
\hline Nematodes & 1 & $01 / 06$ & $-11.6 \pm 0.3^{a}$ & $9.9 \pm 0.4^{\mathrm{a}}$ & $46.1 \pm 1.2$ & $11.6 \pm 0.4$ & $4.7 \pm 0.0$ \\
\hline Nematodes & 2 & $01 / 06$ & $-12.5 \pm 0.1^{b}$ & $10.0 \pm 0.7^{\mathrm{a}}$ & $47.1 \pm 0.9$ & $11.4 \pm 0.3$ & $4.8 \pm 0.2$ \\
\hline Nematodes & 3 & $01 / 06$ & $-14.2 \pm 0.4^{\mathrm{c}}$ & $9.1 \pm 0.2^{\mathrm{b}}$ & $47.1 \pm 0.6$ & $11.2 \pm 0.1$ & $4.9 \pm 0.1$ \\
\hline Harpacticoid copepods & 1 & $01 / 06$ & $-12.8 \pm 0.2^{\mathrm{a}}$ & $8.6 \pm 0.1^{\mathrm{a}}$ & $49.9 \pm 0.6$ & $11.2 \pm 0.2$ & $5.2 \pm 0.1$ \\
\hline Harpacticoid copepods & 2 & $01 / 06$ & $-11.9 \pm 0.6^{\mathrm{a}}$ & $8.7 \pm 0.1^{\mathrm{a}}$ & $46.6 \pm 3.0$ & $11.6 \pm 0.5$ & $4.7 \pm 0.1$ \\
\hline Harpacticoid copepods & 3 & $01 / 06$ & $-12.8 \pm 1.0^{\mathrm{a}}$ & $8.5 \pm 0.6^{\mathrm{a}}$ & $47.2 \pm 1.1$ & $10.5 \pm 0.3$ & $5.2 \pm 0.0$ \\
\hline${ }^{*}$ From Leduc et al. 2006 & & & & & & & \\
\hline
\end{tabular}

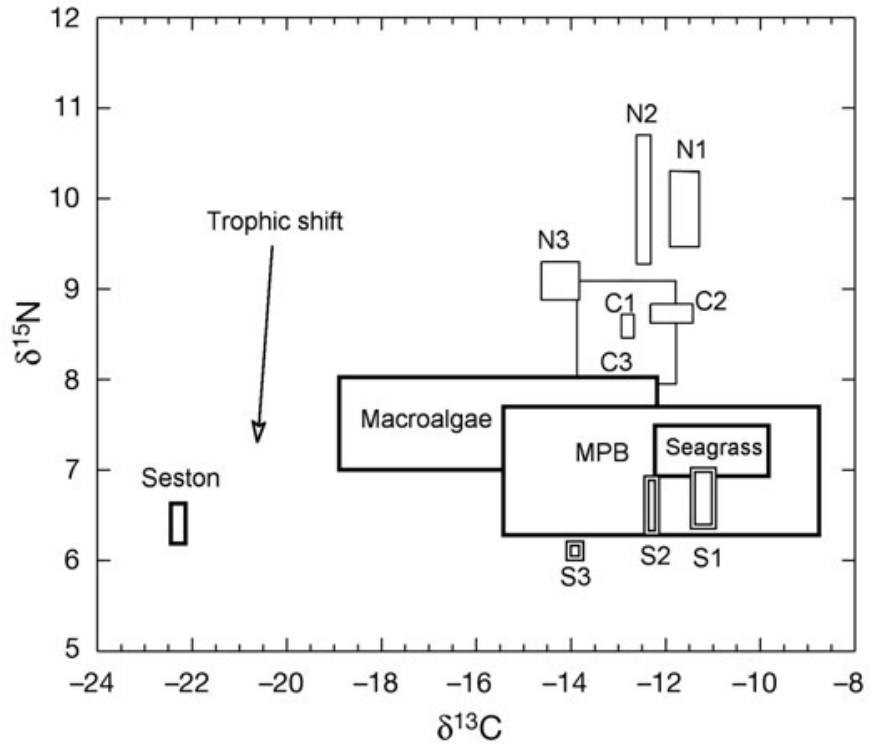

Fig. 2. $\delta^{13} \mathrm{C}$ versus $\delta^{15} \mathrm{~N}$ plots of primary producers, sediment organic matter (SOM), and meiofauna in an intertidal Zostera muelleri bed (Sites 2 and 3) and adjacent unvegetated sediments (Site 1) at Papanui Inlet (box, mean $\pm \mathrm{SD}, \mathrm{n}=3$ to 15 ). Numbers after the data labels indicate the site the samples were taken from. Meiofauna (single lines): $\mathrm{N}$, nematodes; $\mathrm{C}$, harpacticoid copepods. SOM (double lines): S, fine $(<125 \mu \mathrm{m})$ fraction. MPB, microphytobenthos. The trophic-shift arrow shows the direction and magnitude of the trophic shift for animals analyzed whole $\left(+0.3\right.$ and $+2.1 \%$ for $\delta^{13} \mathrm{C}$ and $\delta^{15} \mathrm{~N}$, respectively; McCutchan et al. 2003). Isotopic values for seston were obtained from Leduc et al. (2006). See Table 1 for details of samples collected 
$18: 3 \mathrm{n} 3$ and $18: 2 \mathrm{n} 6$ (45 and $10 \%$ of total, respectively). The relative abundance of 18:3n 3 declined sharply to $9 \%$ in $4 \mathrm{wk}$ old detritus, whereas the abundance of most saturated FAs (e.g. 14:0, 16:0, 24:0) as well as 18:1n7 and 18:1n9 were significantly higher in detritus ( $t$-test, $\mathrm{p}<0.05)$. Ulva sp. and Enteromorpha sp. were characterized by relatively high levels of 18:1n7 (>10\%). Enteromorpha sp. was also characterized by high levels of $14: 0$ and 18:2n6 (>14\%). Polysiphonia sp. was rich in the HUFAs $20: 5 n 3$ and 20:4n6 (29 and 10\%, respectively). Dinoflagellate and diatom biofilm was also rich in HUFAs $(20: 5 n 3,18: 4 n 3$, and 18:5n3), and had elevated levels (>5\%) of 16:1n7, 15:0, and 14:0. Cyanobacterial biofilm had relatively high (14\%) concentrations of 18:3n3.
SOM FAs were primarily 16:0, 16:1n7, and 18:0 (Table 3). A greater number of FAs were detected in the fine fraction $(<125 \mu \mathrm{m})$ than in bulk SOM of Sites 1 and 2 (e.g. 14 vs. 21 FAs in bulk and fine SOM fractions of Site 1, respectively). Relatively high levels of 14:0 (5\%) were found at Sites 1 and 2. Abundances of 15:0 and 18:1n7 were highest at Sites 2 (5 to 6\%) and 3 (5\%), respectively. The most common HUFA was $20: 5 n 3$, with the highest abundance $(7 \%)$ in the fine fraction of Site 1, and the lowest abundance $(1 \%)$ in the fine fraction of Site 3 . The abundance of other HUFAs, such as 18:4n3 and 22:6n3, was $<3 \%$ at all sites.

Two-way ANOSIM revealed significant differences in the FA composition of SOM between sites and size fractions (Table 4). Comparison of SOM and organic

Table 2. Fatty acid (FA) composition ( $\%$ of total FAs, mean \pm SD, $n=3$ ) of total lipid extracted from primary producers in Papanui Inlet. Values of the 5 most abundant FAs are in bold. $\Sigma=$ sum, HUFAs $=$ highly unsaturated FAs. Superscripted letters denote that mean values for Zostera muelleri blades and detritus are not significantly different (Student's $t$-test, $\mathrm{p}>0.05$ )

\begin{tabular}{|c|c|c|c|c|c|c|c|}
\hline FA & $\begin{array}{l}\text { Z. muelleri } \\
\text { blades }\end{array}$ & $\begin{array}{l}\text { Z. muelleri } \\
\text { detritus }\end{array}$ & Ulva sp. & Enteromorpha sp. & Polysiphonia sp. & $\begin{array}{c}\text { Dinofagellate }+ \\
\text { diatom biofilm }\end{array}$ & $\begin{array}{c}\text { Cyanobacteria } \\
\text { biofilm }\end{array}$ \\
\hline $13: 0$ & 0.0 & $1.5 \pm 0.9$ & 0.0 & $0.3 \pm 0.1$ & 0.0 & $1.3 \pm 0.1$ & $0.2 \pm 0.0$ \\
\hline $14: 0$ & $0.3 \pm 0.0^{\mathrm{a}}$ & $3.2 \pm 1.4^{\mathrm{b}}$ & $0.9 \pm 0.1$ & $14.1 \pm 0.4$ & $4.1 \pm 0.1$ & $5.0 \pm 0.1$ & $1.4 \pm 0.1$ \\
\hline $14: 1$ & $0.2 \pm 0.1$ & 0.0 & 0.0 & 0.0 & 0.0 & 0.0 & $0.9 \pm 0.0$ \\
\hline $15: 0$ & $0.2 \pm 0.0^{\mathrm{a}}$ & $0.8 \pm 0.5^{\mathrm{b}}$ & $0.3 \pm 0.0$ & $0.1 \pm 0.0$ & $0.2 \pm 0.0$ & $5.2 \pm 0.1$ & $0.2 \pm 0.1$ \\
\hline $15: 1$ & 0.0 & 0.0 & 0.0 & 0.0 & 0.0 & 0.0 & 0.0 \\
\hline $16: 0$ & $14.1 \pm 0.3^{\mathrm{a}}$ & $20.5 \pm 1.5^{b}$ & $46.0 \pm 2.6$ & $21.9 \pm 1.2$ & $26.7 \pm 0.6$ & $16.4 \pm 0.1$ & $32.1 \pm 0.8$ \\
\hline $16: 1 \mathrm{n} 7$ & $2.0 \pm 0.0^{\mathrm{a}}$ & $2.9 \pm 0.3^{\mathrm{b}}$ & $3.5 \pm 0.1$ & $0.8 \pm 0.6$ & $1.8 \pm 0.0$ & $7.5 \pm 0.1$ & $2.8 \pm 0.3$ \\
\hline $16: 4 n 3$ & $0.1 \pm 0.0^{\mathrm{a}}$ & $0.1 \pm 0.1^{\mathrm{a}}$ & $2.2 \pm 0.1$ & 0.0 & $0.2 \pm 0.0$ & 0.0 & $0.1 \pm 0.0$ \\
\hline $17: 0$ & $0.1 \pm 0.0^{\mathrm{a}}$ & $0.7 \pm 0.1^{b}$ & 0.0 & 0.0 & 0.0 & $0.4 \pm 0.0$ & $0.9 \pm 0.0$ \\
\hline $18: 0$ & $2.0 \pm 0.0^{\mathrm{a}}$ & $4.3 \pm 0.6^{b}$ & $0.8 \pm 0.1$ & $0.2 \pm 0.0$ & $0.9 \pm 0.0$ & $0.5 \pm 0.1$ & $2.8 \pm 0.2$ \\
\hline $18: 1 \mathrm{n} 9$ & $0.7 \pm 0.1^{\mathrm{a}}$ & $2.8 \pm 0.3^{b}$ & $1.9 \pm 0.4$ & $0.6 \pm 0.6$ & $3.9 \pm 0.1$ & 0.0 & $1.6 \pm 0.0$ \\
\hline $18: 1 \mathrm{n} 7$ & $0.5 \pm 0.0^{\mathrm{a}}$ & $3.2 \pm 0.4^{\mathrm{b}}$ & $13.2 \pm 0.2$ & $10.5 \pm 1.1$ & $1.0 \pm 0.1$ & $1.6 \pm 0.0$ & $1.3 \pm 0.1$ \\
\hline $18: 2 \mathrm{n} 6$ & $10.2 \pm 0.0^{\mathrm{a}}$ & $3.7 \pm 0.3^{b}$ & $2.1 \pm 0.0$ & $14.3 \pm 0.8$ & $1.1 \pm 0.0$ & $1.0 \pm 0.0$ & $1.4 \pm 0.1$ \\
\hline $18: 3 n 6$ & 0.0 & $0.1 \pm 0.1$ & $0.2 \pm 0.2$ & $0.8 \pm 0.0$ & $0.2 \pm 0.2$ & $0.2 \pm 0.1$ & $0.1 \pm 0.0$ \\
\hline $18: 3 n 3$ & $45.9 \pm 0.7^{\mathrm{a}}$ & $8.5 \pm 0.4^{b}$ & $4.1 \pm 0.4$ & $0.5 \pm 0.1$ & $0.5 \pm 0.0$ & $2.5 \pm 0.0$ & $14.4 \pm 0.7$ \\
\hline $18: 4 \mathrm{n} 3$ & $0.4 \pm 0.1$ & 0.0 & 0.0 & $0.3 \pm 0.1$ & 0.0 & $10.4 \pm 0.1$ & $0.3 \pm 0.1$ \\
\hline $18: 5 n 3$ & 0.0 & 0.0 & 0.0 & 0.0 & 0.0 & $10.4 \pm 0.2$ & 0.0 \\
\hline 20:0 & $1.2 \pm 0.0^{\mathrm{a}}$ & $2.0 \pm 0.2^{b}$ & 0.0 & $0.1 \pm 0.0$ & 0.0 & $0.1 \pm 0.0$ & $0.3 \pm 0.0$ \\
\hline $20: 1$ & $0.1 \pm 0.0^{\mathrm{a}}$ & $0.1 \pm 0.1^{\mathrm{a}}$ & $0.2 \pm 0.0$ & $0.6 \pm 0.1$ & $0.2 \pm 0.0$ & 0.0 & $0.1 \pm 0.0$ \\
\hline $20: 2 \mathrm{n} 6$ & $0.1 \pm 0.0^{\mathrm{a}}$ & $0.1 \pm 0.0^{\mathrm{a}}$ & 0.0 & $0.8 \pm 0.0$ & $0.9 \pm 0.2$ & $0.1 \pm 0.0$ & $0.5 \pm 0.8$ \\
\hline 20:3n3 & $0.3 \pm 0.0^{\mathrm{a}}$ & $0.2 \pm 0.2^{\mathrm{a}}$ & $0.3 \pm 0.0$ & $2.1 \pm 0.0$ & $0.5 \pm 0.2$ & $0.6 \pm 0.0$ & $0.2 \pm 0.0$ \\
\hline 20:3n6 & 0.0 & $0.1 \pm 0.1$ & $0.2 \pm 0.0$ & $0.2 \pm 0.0$ & $3.3 \pm 0.1$ & $0.5 \pm 0.0$ & $0.4 \pm 0.0$ \\
\hline 20:4n3 & $0.2 \pm 0.0^{\mathrm{a}}$ & $0.3 \pm 0.1^{\mathrm{a}}$ & $0.1 \pm 0.0$ & $0.9 \pm 0.1$ & $0.2 \pm 0.2$ & $1.0 \pm 0.0$ & $0.8 \pm 0.1$ \\
\hline $20: 4 \mathrm{n} 6$ & $0.1 \pm 0.0^{\mathrm{a}}$ & $0.5 \pm 0.0^{b}$ & $0.3 \pm 0.0$ & $0.2 \pm 0.0$ & $9.6 \pm 0.2$ & $0.5 \pm 0.0$ & $1.3 \pm 0.1$ \\
\hline $20: 5 n 3$ & $0.1 \pm 0.0$ & 0.0 & $0.7 \pm 0.1$ & $0.6 \pm 0.0$ & $29.1 \pm 0.2$ & $15.4 \pm 0.2$ & $1.1 \pm 0.1$ \\
\hline $22: 0$ & $1.8 \pm 0.1^{\mathrm{a}}$ & $4.2 \pm 0.4^{b}$ & $3.9 \pm 0.1$ & $0.4 \pm 0.1$ & $0.1 \pm 0.0$ & $0.1 \pm 0.0$ & $0.5 \pm 0.0$ \\
\hline $22: 1$ & 0.0 & 0.0 & $0.3 \pm 0.3$ & $0.1 \pm 0.1$ & $0.4 \pm 0.0$ & 0.0 & $0.1 \pm 0.0$ \\
\hline $22: 2 \mathrm{n} 6$ & 0.0 & $1.2 \pm 1.2$ & 0.0 & $0.3 \pm 0.0$ & $0.1 \pm 0.0$ & 0.0 & $0.1 \pm 0.0$ \\
\hline $22: 4 \mathrm{n} 6$ & $0.3 \pm 0.0^{\mathrm{a}}$ & $0.5 \pm 0.4^{\mathrm{a}}$ & 0.0 & $0.1 \pm 0.1$ & 0.0 & 0.0 & 0.0 \\
\hline $22: 5 n 3$ & 0.0 & 0.0 & $2.2 \pm 0.3$ & $1.0 \pm 0.0$ & 0.0 & $1.1 \pm 0.0$ & $0.1 \pm 0.1$ \\
\hline $22: 6 n 3$ & 0.0 & 0.0 & $0.2 \pm 0.0$ & 0.0 & $0.3 \pm 0.1$ & $2.5 \pm 0.0$ & $0.5 \pm 0.1$ \\
\hline $24: 0$ & $1.1 \pm 0.0^{\mathrm{a}}$ & $4.4 \pm 0.4^{b}$ & $0.4 \pm 0.0$ & $1.5 \pm 0.0$ & 0.0 & $0.4 \pm 0.4$ & $0.7 \pm 0.0$ \\
\hline $\begin{array}{l}\Sigma \text { Satur- } \\
\text { ated FAs }\end{array}$ & 20.8 & 41.6 & 52.3 & 38.6 & 31.9 & 29.4 & 39.1 \\
\hline$\Sigma$ HUFAs & 1.0 & 1.6 & 4.0 & 5.1 & 43.0 & 21.6 & 4.1 \\
\hline
\end{tabular}


Table 3. Fatty acid (FA) composition ( $\%$ of total FAs, mean $\pm \mathrm{SD}, \mathrm{n}=3$ ) of total lipid extracted from sediments of Sites 1 (unvegetated sediments), 2 (sparse Zostera muelleri bed), and 3 (dense Z. muelleri bed) at Papanui Inlet in January 2006. The 5 most abundant FAs in each sediment type are in bold. $\Sigma=$ sum, HUFAs = highly unsaturated FAs. Mean values marked by the same superscripted letter are not significantly different between sites, and mean values marked by the same superscripted number are not different between bulk and small $(<125 \mu \mathrm{m})$ fractions (2-way ANOVA or 1-way ANOVA with post hoc Tukey's test, or Student's t-test, $\mathrm{p}>0.05$ )

\begin{tabular}{|c|c|c|c|c|c|c|}
\hline \multirow[b]{2}{*}{ FA } & \multicolumn{2}{|c|}{ Site 1} & \multicolumn{2}{|c|}{ Site 2} & \multirow[b]{2}{*}{ Bulk } & \multirow{2}{*}{ Site $3 \stackrel{ }{<125 \mu \mathrm{m}}$} \\
\hline & Bulk & $<125 \mu \mathrm{m}$ & Bulk & $<125 \mu \mathrm{m}$ & & \\
\hline $13: 0$ & 0.0 & $0.3 \pm 0.3^{\mathrm{a}}$ & 0.0 & $0.5 \pm 0.2^{\mathrm{a}}$ & 0.0 & $0.5 \pm 0.2^{\mathrm{a}}$ \\
\hline $14: 0$ & $5.3 \pm 0.3^{a_{1} 1}$ & $4.7 \pm 0.7^{\mathrm{a}, 1}$ & $5.8 \pm 0.5^{a, 1}$ & $4.9 \pm 1.6^{a_{1} 1}$ & $4.2 \pm 0.4^{\mathrm{b}, 1}$ & $2.4 \pm 0.8^{\mathrm{b}, 2}$ \\
\hline $14: 1$ & 0.0 & 0.0 & 0.0 & 0.0 & 0.0 & 0.0 \\
\hline $15: 0$ & $1.9 \pm 0.2^{\mathrm{a}, 1}$ & $3.3 \pm 0.2^{\mathrm{a}, 2}$ & $6.0 \pm 0.6^{b, 1}$ & $4.9 \pm 0.2^{\mathrm{a}, 2}$ & $2.5 \pm 0.2^{\mathrm{c}, 1}$ & $1.0 \pm 0.2^{b, 2}$ \\
\hline $15: 1$ & 0.0 & 0.0 & $0.3 \pm 0.2^{\mathrm{a}}$ & 0.0 & $0.1 \pm 0.1^{\mathrm{a}}$ & 0.0 \\
\hline $16: 0$ & $29.1 \pm 0.8^{\mathrm{a}, 1}$ & $29.0 \pm 1.0^{a, 1}$ & $29.2 \pm 2.5^{\mathrm{a}, 1}$ & $25.9 \pm 0.5^{b, 1}$ & $22.7 \pm 2.2^{\mathrm{a}, 1}$ & $18.6 \pm 2.8^{\mathrm{c}, 1}$ \\
\hline $16: 1 \mathrm{n} 7$ & $15.1 \pm 2.3^{\mathrm{a}, 1}$ & $12.3 \pm 1.5^{\mathrm{a}, 1}$ & $21.8 \pm 2.5^{\mathrm{a}, 1}$ & $11.1 \pm 1.3^{\mathrm{a}, 2}$ & $18.5 \pm 0.6^{\mathrm{a}, \mathrm{b}, 1}$ & $5.26 \pm 1.0^{b, 1}$ \\
\hline $16: 4 \mathrm{n} 3$ & 0.0 & $0.6 \pm 0.1^{\mathrm{a}}$ & 0.0 & $0.1 \pm 0.0^{\mathrm{b}}$ & 0.0 & $0.4 \pm 0.3^{\mathrm{a}, \mathrm{b}}$ \\
\hline $17: 0$ & 0.0 & $1.8 \pm 0.1^{\mathrm{a}}$ & $1.3 \pm 1.1^{\mathrm{a}, 1}$ & $1.1 \pm 0.0^{\mathrm{b}, 1}$ & $2.3 \pm 0.2^{\mathrm{a}, 1}$ & $1.2 \pm 1.0^{\mathrm{a}, \mathrm{b}, 1}$ \\
\hline $18: 0$ & $7.3 \pm 0.8^{a_{1} 1}$ & $6.4 \pm 0.8^{a, 1}$ & $4.9 \pm 0.2^{b, 1}$ & $4.3 \pm 0.4^{b, 1}$ & $4.8 \pm 0.6^{b, 1}$ & $6.8 \pm 0.6^{\mathrm{a}, 2}$ \\
\hline $18: 1 \mathrm{n} 9$ & $1.1 \pm 1.0^{\mathrm{a}, 1}$ & $3.7 \pm 1.1^{\mathrm{a}, 2}$ & $2.6 \pm 0.7^{a, b, 1}$ & $3.0 \pm 0.4^{\mathrm{a}, 1}$ & $2.8 \pm 0.2^{\mathrm{b}, 1}$ & $3.6 \pm 1.0^{\mathrm{a}, 1}$ \\
\hline $18: 1 \mathrm{n} 7$ & 0.0 & $1.7 \pm 0.1^{\mathrm{a}}$ & $2.2 \pm 0.3^{\mathrm{a}, 1}$ & $2.1 \pm 0.2^{\mathrm{a}, 1}$ & $4.2 \pm 0.5^{b, 1}$ & $4.5 \pm 0.9^{b, 1}$ \\
\hline $18: 2 \mathrm{n} 6$ & 0.0 & $0.8 \pm 0.1^{\mathrm{a}, \mathrm{b}}$ & 0.0 & $0.6 \pm 0.1^{\mathrm{a}}$ & $0.4 \pm 0.6^{1}$ & $0.9 \pm 0.2^{\mathrm{b}, 1}$ \\
\hline $18: 3 n 6$ & 0.0 & $0.2 \pm 0.2^{\mathrm{a}}$ & 0.0 & $0.3 \pm 0.1^{\mathrm{a}}$ & 0.0 & $0.2 \pm 0.1^{\mathrm{a}}$ \\
\hline $18: 3 n 3$ & 0.0 & $0.9 \pm 0.0^{\mathrm{a}}$ & 0.0 & $0.5 \pm 0.1^{\mathrm{b}}$ & $0.5 \pm 0.7^{1}$ & $0.5 \pm 0.2^{\mathrm{b}, 1}$ \\
\hline $18: 4 \mathrm{n} 3$ & 0.0 & $1.3 \pm 0.1^{\mathrm{a}}$ & 0.0 & $0.3 \pm 0.0^{\mathrm{b}}$ & 0.0 & 0.0 \\
\hline $18: 5 \mathrm{n} 3$ & 0.0 & $0.1 \pm 0.1^{\mathrm{a}}$ & 0.0 & $0.2 \pm 0.1^{\mathrm{a}}$ & 0.0 & 0.0 \\
\hline $20: 0$ & 0.0 & $1.0 \pm 0.1^{\mathrm{a}}$ & 0.0 & $0.9 \pm 0.1^{\mathrm{a}}$ & 0.0 & $1.4 \pm 0.1^{\mathrm{b}}$ \\
\hline $20: 1$ & 0.0 & 0.0 & $0.1 \pm 0.1^{\mathrm{a}, 1}$ & $0.1 \pm 0.1^{1}$ & $0.2 \pm 0.0^{\mathrm{a}}$ & 0.0 \\
\hline $20: 2 n 6$ & $1.6 \pm 0.5^{\mathrm{a}}$ & 0.0 & $0.2 \pm 0.2^{\mathrm{b}}$ & 0.0 & $0.3 \pm 0.1^{b}$ & 0.0 \\
\hline $20: 3 n 3$ & $3.3 \pm 0.2^{\mathrm{a}}$ & 0.0 & $2.3 \pm 0.6^{\mathrm{b}}$ & 0.0 & $1.3 \pm 0.4^{\mathrm{b}}$ & 0.0 \\
\hline $20: 3 n 6$ & 0.0 & 0.0 & 0.0 & $0.2 \pm 0.0^{\mathrm{a}}$ & $0.3 \pm 0.3^{1}$ & $0.4 \pm 0.1^{a, 1}$ \\
\hline $20: 4 n 3$ & $0.6 \pm 0.1$ & $1.4 \pm 0.1^{\mathrm{a}, 2}$ & 0.0 & $1.3 \pm 0.1^{\mathrm{a}}$ & 0.0 & $0.8 \pm 0.2^{\mathrm{b}}$ \\
\hline $20: 4 n 6$ & $1.0 \pm 0.1^{\mathrm{a}}$ & 0.0 & $1.3 \pm 0.3^{\mathrm{a}, 1}$ & $0.6 \pm 0.5^{1}$ & $1.8 \pm 0.2^{\mathrm{b}}$ & 0.0 \\
\hline $20: 5 n 3$ & $2.8 \pm 0.7^{a, 1}$ & $6.5 \pm 0.5^{a, 2}$ & $3.6 \pm 0.7^{a, 1}$ & $2.8 \pm 0.4^{b, 1}$ & $4.5 \pm 1.0^{\mathrm{a}, 1}$ & $1.1 \pm 0.3^{\mathrm{c}, 2}$ \\
\hline $22: 0$ & $0.4 \pm 0.4^{\mathrm{a}, 1}$ & $1.4 \pm 0.1^{\mathrm{a}, 2}$ & $0.8 \pm 0.1^{\mathrm{a}, 1}$ & $1.2 \pm 0.1^{\mathrm{a}, 2}$ & $1.5 \pm 0.2^{b, 1}$ & $2.3 \pm 0.0^{\mathrm{b}, 2}$ \\
\hline $22: 1$ & 0.0 & 0.0 & 0.0 & $0.2 \pm 0.2$ & 0.0 & 0.0 \\
\hline $22: 2 \mathrm{n} 6$ & 0.0 & 0.0 & $1.1 \pm 0.2^{\mathrm{a}}$ & 0.0 & $0.6 \pm 0.6^{a}$ & 0.0 \\
\hline $22: 4 \mathrm{n} 6$ & 0.0 & 0.0 & 0.0 & 0.0 & $0.4 \pm 0.0^{1}$ & $0.2 \pm 0.2^{1}$ \\
\hline $22: 5 n 3$ & 0.0 & 0.0 & $0.3 \pm 0.1^{a, 1}$ & $0.5 \pm 0.4^{\mathrm{a}, 1}$ & $0.6 \pm 0.2^{\mathrm{a}, 1}$ & $0.5 \pm 0.1^{a, 1}$ \\
\hline $22: 6 \mathrm{n} 3$ & 0.0 & $2.2 \pm 0.3^{\mathrm{a}}$ & $0.4 \pm 0.4^{a, 1}$ & $0.6 \pm 0.2^{b, 1}$ & $0.5 \pm 0.1^{\mathrm{a}}$ & 0.0 \\
\hline $24: 0$ & $0.9 \pm 0.0^{\mathrm{a}, 1}$ & $2.0 \pm 0.0^{\mathrm{a}, 2}$ & $1.0 \pm 0.1^{\mathrm{a}, 1}$ & $1.9 \pm 0.1^{\mathrm{a}, 2}$ & $2.1 \pm 0.1^{b, 1}$ & $3.7 \pm 0.2^{b, 2}$ \\
\hline $\begin{array}{c}\text { Bacterial }(\Sigma 15, \\
\Sigma 17,18: 1 \mathrm{n} 7)\end{array}$ & 1.9 & 6.8 & 9.8 & 9.1 & 9.0 & 6.7 \\
\hline$\Sigma$ HUFAs & 7.7 & 10.1 & 7.9 & 6.0 & 7.7 & 2.7 \\
\hline
\end{tabular}

matter source FA composition on the MDS plot showed that several sources were likely to contribute to SOM at the study sites (Fig. 3). The FA composition of SOM at all sites was intermediate between macroalgae, MPB, and Zostera muelleri detritus. Fine SOM from Site 3 was closest to $Z$. muelleri detritus.

\section{Feeding experiment and harpacticoid copepod FA profiles}

Meiofaunal abundance and biomass in the microcosms was dominated by the harpacticoid copepod Parastenhelia megarostrum (Table 5). The presence of microalgae (mostly dinoflagellates and some Euglena sp.), as well as numerous ciliates and other
Table 4. Results of 2-way analysis of similarities (ANOSIM; based on 999 permutations) testing differences in fatty acid composition of sediment organic matter between 3 sites ( $1=$ unvegetated, 2 = sparse Zostera muelleri, 3 = dense $Z$. muelleri) and size fractions (bulk vs. $<125 \mu \mathrm{m}$ ), with details of global and pairwise comparisons. Results in bold are significant at $\alpha=0.05$ (global R value) or 0.017 (pairwise comparisons with Bonferroni corrections)

\begin{tabular}{|lcc|}
\hline Factor & $\mathrm{R}$ & Significance level (\%) \\
\hline Site & & \\
Global ANOSIM & 1.0 & $\mathbf{0 . 1}$ \\
$1-2$ & 1.0 & $\mathbf{1 . 0}$ \\
$1-3$ & 1.0 & $\mathbf{1 . 0}$ \\
$2-3$ & 1.0 & $\mathbf{1 . 0}$ \\
Size fraction & & \\
Global ANOSIM & 1.0 & $\mathbf{0 . 3}$ \\
\hline
\end{tabular}




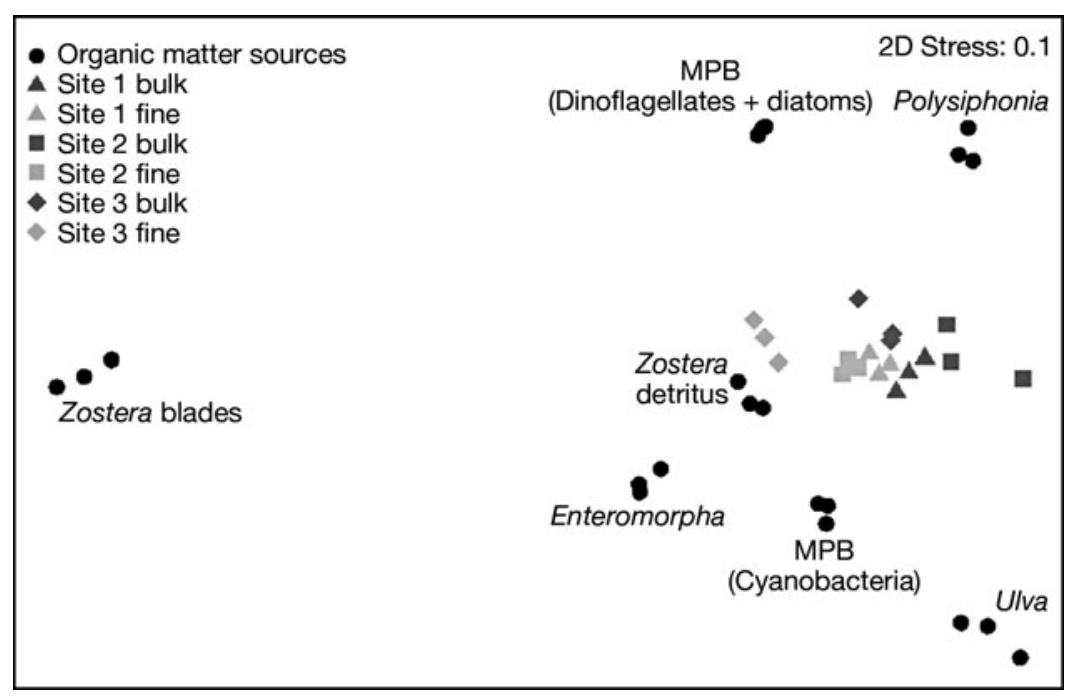

Fig. 3. Two-dimensional MDS configuration for the fatty acid composition of primary producers $(\bullet)$, fine sediment organic matter $\left(\mathrm{SOM}_{i}<125 \mu \mathrm{m}\right)$, and bulk SOM from Papanui Inlet, January 2006. MPB, microphytobenthos. Site 1: unvegetated sediments, 2: sparse Zostera muelleri meadow, 3: dense Z. muelleri meadow

protists associated with the Enteromorpha sp. detritus, were observed in sediment aliquots throughout the experiment. Pink coloration of the detritus (apparent $4 \mathrm{~d}$ after the beginning of the experiment) was indicative of bacterial growth, as ascertained through observation of aliquots under a compound microscope.

An enriched $\delta^{13} \mathrm{C}$ signature of $284 \%$ (equivalent to $1.422 \%$ of Enteromorpha sp. carbon present as ${ }^{13} \mathrm{C}$ ) was achieved for Enteromorpha sp. after labeling (Table 6). The FA profile of Enteromorpha sp. was characterized by high levels of 16:0, 18:2n6, 18:1n7, and 14:0.

The $\delta^{13} \mathrm{C}$ and $\delta^{15} \mathrm{~N}$ signatures of harpacticoid copepods at the beginning of the experiment were -15.6 and $8.1 \%$, respectively. The $\delta^{13} \mathrm{C}$ signature of harpacticoid copepods was significantly higher in treatment microcosms relative to controls at the end of the experiment $(-9.9$ vs. $-15.8 \%$, $p<0.05)$. The $\delta^{15} \mathrm{~N}$

Table 5. Abundance and biomass (mean $\pm \mathrm{SD}$ ) of harpacticoid copepods and meiofauna in the sediment used for the microcosm experiment, January 2007

\begin{tabular}{|lcc|}
\hline & $\begin{array}{c}\text { Abundance } \\
\left(10 \mathrm{~cm}^{-2}\right)\end{array}$ & $\begin{array}{c}\text { Biomass } \\
\left(\mathrm{mg} \mathrm{DW} \mathrm{m}^{-2}\right)\end{array}$ \\
\hline Parastenhelia megarostrum & $557 \pm 210$ & $270 \pm 102$ \\
Other harpacticoid copepods & $72 \pm 20$ & $4 \pm 1$ \\
Nauplii & $506 \pm 177$ & $<1$ \\
Nematodes & $359 \pm 101$ & $60 \pm 18$ \\
Total meiofauna & $\mathbf{1 4 9 6} \pm \mathbf{1 7 7}$ & $\mathbf{3 3 4} \pm \mathbf{1 0 4}$ \\
\hline
\end{tabular}

signature of harpacticoid copepods was also significantly higher in treatments than controls (8.7 vs. $8.0 \%$, p < $0.05)$. The mean $\pm \mathrm{SD}$ incorporation rate of Enteromorpha sp. detritus by harpacticoid copepods was $2.6 \pm$ $0.6 \mu \mathrm{g} \mathrm{DW} \mathrm{Dnteromorpha} \mathrm{sp.}_{\mathrm{mg} \mathrm{DW}} \mathrm{DW}_{\text {copepod }}$ $\mathrm{d}^{-1}(\mathrm{n}=4)$ and represented $<5 \%$ of their estimated carbon demand.

The FA composition of harpacticoid copepods from the field was characterized by high levels of 16:0, 22:6n3, 16:1n7, and 20:5n3 (Table 6). Copepod FA profiles were similar between vegetated and unvegetated sites, but significantly higher abundances of $16: 4 \mathrm{n} 3$, as well as of the bacterial FAs 15:0, 17:0, and 18:1n7 were found in copepods from the vegetated site (ANOVA and Tukey's post hoc test, $\mathrm{p}<0.05)$. The concentrations of $14: 0,20: 5 \mathrm{n} 3$, and 22:5n 3 in harpacticoid copepods were significantly lower at the end of the experiment in both treatments and controls $(p<0.05)$. Levels of 16:0 and 16:1n7 were also significantly lower than initial levels in the treatment microcosms $(p<0.05)$. The relative abundance of 17:0 was significantly higher at the end of the experiment in both treatments and controls, but the observed differences were slight ( 0.3 to $1.0 \%, \mathrm{p}<0.05$ ). No significant difference was found in the abundance of any harpacticoid copepod FAs between control and treatment microcosms in the feeding experiment $(\mathrm{p}>0.05)$.

\section{DISCUSSION}

\section{Potential food sources}

A wide variety of food sources are available to consumers in seagrass beds. Microalgal biofilms may comprise several unrelated taxa such as diatoms, dinoflagellates, and euglenoids, but few studies have attempted to identify which groups are present. Careful examinations of MPB samples, however, can reveal the presence of unexpected taxa (e.g. cyanobacteria; Cook et al. 2004). The composition of MPB in the present study varied both in time and in space. Diatoms, which usually dominate MPB in coastal areas, were never abundant. Sampling MPB on different occasions allowed the determination of isotopic and FA composition of taxa that, although not dominant at the time of sampling, could still represent important food sources. For example, cyanobacteria were observed in meio- 
Table 6. Isotopic and fatty acid (FA) composition of Enteromorpha sp. detritus and of harpacticoid copepods from Papanui Inlet and from the feeding experiment (January 2007). Results are mean \pm SD ( $n=3$ to 4). The 5 most abundant FAs in each sample type are in bold. Values for harpacticoid copepods followed by the same letter are not significantly different (1-way ANOVA, $\mathrm{p}<0.05) . \Sigma=$ sum, HUFAs = highly unsaturated FAs, nd = no data. Superscripted letter denote values for harpacticoid copepods that are not significantly different $(1$-way ANOVA, $\mathrm{p}<0.05)$

\begin{tabular}{|c|c|c|c|c|c|}
\hline FA & $\begin{array}{l}\text { Harpacticoid } \\
\text { copepods } \\
\text { (vegetated } \\
\text { sediments) }\end{array}$ & $\begin{array}{l}\text { Harpacticoid } \\
\text { copepods } \\
\text { (unvegetated } \\
\text { sediments) } \\
\text { Initial }\end{array}$ & $\begin{array}{l}\text { Harpacticoid } \\
\text { copepods } \\
\text { Control }\end{array}$ & $\begin{array}{c}\text { Harpacticoid } \\
\text { copepods } \\
\text { Treatment }\end{array}$ & Enteromorpha sp. \\
\hline $13: 0$ & 0.0 & 0.0 & 0.0 & 0.0 & 0.0 \\
\hline $14: 0$ & $1.4 \pm 0.1^{\mathrm{a}}$ & $1.7 \pm 0.3^{\mathrm{a}}$ & $1.0 \pm 0.3^{b}$ & $0.8 \pm 0.3^{b}$ & $11.2 \pm 0.3$ \\
\hline 14.1 & 0.0 & 0.0 & 0.0 & 0.0 & 0.0 \\
\hline $15: 0$ & $0.7 \pm 0.1^{\mathrm{a}}$ & $0.7 \pm 0.1^{\mathrm{a}}$ & $0.6 \pm 0.1^{\mathrm{a}}$ & $0.6 \pm 0.1^{\mathrm{a}}$ & 0.0 \\
\hline $16: 0$ & $17.7 \pm 2.0^{\mathrm{a}}$ & $21.8 \pm 0.8^{b}$ & $18.1 \pm 3.8^{a, b}$ & $16.8 \pm 2.7^{\mathrm{a}}$ & $35.0 \pm 1.5$ \\
\hline $16: 1 \mathrm{n} 7$ & $12.1 \pm 2.7^{a}$ & $14.0 \pm 3.7^{a}$ & $8.1 \pm 4.9^{\mathrm{a}, \mathrm{b}}$ & $6.1 \pm 3.7^{b}$ & $1.5 \pm 0.1$ \\
\hline $16: 4 n 3$ & $2.4 \pm 0.9^{\mathrm{a}}$ & $0.5 \pm 0.1^{\mathrm{b}}$ & $0.4 \pm 0.1^{\mathrm{b}}$ & $0.4 \pm 0.0^{\mathrm{b}}$ & 0.0 \\
\hline $17: 0$ & $1.7 \pm 0.7^{\mathrm{a}}$ & $0.4 \pm 0.0^{\mathrm{b}}$ & $0.7 \pm 0.0^{c}$ & $0.8 \pm 0.1^{\mathrm{c}}$ & 0.0 \\
\hline $18: 0$ & $4.6 \pm 0.6^{\mathrm{a}}$ & $4.4 \pm 0.8^{\mathrm{a}}$ & $5.7 \pm 1.2^{\mathrm{a}}$ & $6.2 \pm 1.1^{\mathrm{a}}$ & $0.1 \pm 0.0$ \\
\hline $18: 1 \mathrm{n} 9$ & $1.3 \pm 0.1^{\mathrm{a}}$ & $1.4 \pm 0.8^{\mathrm{a}, \mathrm{b}}$ & $0.9 \pm 0.2^{b}$ & $0.8 \pm 0.2^{\mathrm{b}}$ & $0.5 \pm 0.4$ \\
\hline $18: 1 \mathrm{n} 7$ & $2.6 \pm 0.6^{\mathrm{a}}$ & $1.6 \pm 0.4^{\mathrm{b}}$ & $1.6 \pm 0.8^{\mathrm{b}}$ & $1.2 \pm 0.6^{b}$ & $12.3 \pm 0.8$ \\
\hline $18: 2 \mathrm{n} 6$ & $0.6 \pm 0.1^{\mathrm{a}}$ & $0.7 \pm 0.2^{\mathrm{a}}$ & $0.4 \pm 0.1^{\mathrm{a}}$ & $0.4 \pm 0.1^{\mathrm{a}}$ & $21.0 \pm 0.7$ \\
\hline $18: 3 n 6$ & $0.4 \pm 0.0^{\mathrm{a}}$ & $0.3 \pm 0.1^{\mathrm{a}}$ & $0.2 \pm 0.2^{\mathrm{a}}$ & $0.1 \pm 0.1^{\mathrm{a}}$ & $1.5 \pm 0.2$ \\
\hline $18: 3 n 3$ & 0.0 & 0.0 & 0.0 & 0.0 & $0.2 \pm 0.2$ \\
\hline $18: 4 \mathrm{n} 3$ & $0.5 \pm 0.1^{\mathrm{a}}$ & $0.6 \pm 0.2^{\mathrm{a}}$ & $0.4 \pm 0.2^{\mathrm{a}}$ & $0.3 \pm 0.1^{\mathrm{a}}$ & $0.5 \pm 0.4$ \\
\hline $20: 0$ & $0.2 \pm 0.0^{\mathrm{a}}$ & $0.2 \pm 0.0^{\mathrm{a}}$ & 0.0 & 0.0 & 0.0 \\
\hline $20: 1$ & 0.0 & 0.0 & 0.0 & 0.0 & $0.7 \pm 0.2$ \\
\hline $20: 2 \mathrm{n} 6$ & $0.3 \pm 0.0^{\mathrm{a}}$ & $0.2 \pm 0.2^{\mathrm{a}}$ & 0.0 & 0.0 & $1.2 \pm 0.0$ \\
\hline $20: 3 n 3$ & 0.0 & 0.0 & 0.0 & 0.0 & $1.1 \pm 0.2$ \\
\hline $20: 3 n 6$ & $2.0 \pm 0.3^{\mathrm{a}}$ & $2.1 \pm 0.1^{\mathrm{a}}$ & $2.3 \pm 0.6^{\mathrm{a}}$ & $2.2 \pm 0.4^{\mathrm{a}}$ & $0.1 \pm 0.1$ \\
\hline $20: 4 n 6$ & 0.0 & 0.0 & 0.0 & 0.0 & $0.7 \pm 0.1$ \\
\hline $20: 5 n 3$ & $11.8 \pm 0.5^{\mathrm{a}, \mathrm{b}}$ & $13.0 \pm 0.8^{a}$ & $10.0 \pm 1.5^{b}$ & $9.9 \pm 0.9^{b, c}$ & $0.6 \pm 0.0$ \\
\hline $22: 0$ & $1.2 \pm 0.3^{\mathrm{a}}$ & $1.7 \pm 0.3^{\mathrm{a}}$ & $1.6 \pm 0.0^{\mathrm{a}}$ & $1.7 \pm 0.7^{\mathrm{a}}$ & $0.2 \pm 0.1$ \\
\hline $22: 1$ & $0.3 \pm 0.0^{\mathrm{a}}$ & $0.2 \pm 0.1^{\mathrm{a}}$ & 0.0 & 0.0 & 0.0 \\
\hline $22: 2 \mathrm{n} 6$ & 0.0 & 0.0 & 0.0 & 0.0 & 0.0 \\
\hline $22: 5 n 3$ & $1.1 \pm 0.1^{\mathrm{a}}$ & $0.9 \pm 0.0^{\mathrm{a}}$ & $0.3 \pm 0.3^{\mathrm{b}}$ & $0.1 \pm 0.1^{\mathrm{b}}$ & $1.3 \pm 0.4$ \\
\hline $22: 6 \mathrm{n} 3$ & $17.0 \pm 0.2^{\mathrm{a}}$ & $19.7 \pm 3.6^{a, b}$ & $20.1 \pm 0.5^{b}$ & $21.7 \pm 1.9^{b}$ & 0.0 \\
\hline $24: 0$ & $1.1 \pm 0.2^{\mathrm{a}}$ & $1.1 \pm 0.3^{\mathrm{a}}$ & $1.0 \pm 0.0^{\mathrm{a}}$ & $0.8 \pm 0.5^{\mathrm{a}}$ & $1.1 \pm 0.3$ \\
\hline $\begin{array}{c}\text { Bacterial }(\Sigma 15 \\
\Sigma 17,18: 1 \mathrm{n} 7)\end{array}$ & 6.4 & 2.7 & 2.9 & 2.9 & 12.3 \\
\hline$\Sigma$ HUFAs & 31.9 & 35.7 & 32.7 & 33.9 & 3.8 \\
\hline$\delta^{13} \mathrm{C}$ & nd & $-15.6 \pm 0.2$ & $-15.8 \pm 0.1$ & $-9.9 \pm 2.5$ & $284 \pm 2.0$ \\
\hline$\delta^{15} \mathrm{~N}$ & nd & $8.1 \pm 0.1$ & $8.0 \pm 0.2$ & $8.7 \pm 0.2$ & $7.8 \pm 0.4$ \\
\hline
\end{tabular}

fauna samples obtained in January 2006 (D. Leduc pers. obs.), but no cyanobacterial mats were observed at that time in the field. Sampling MPB at different times of the year also helped better define the range of MPB isotopic signatures. Sampling MPB in January 2006 only, for example, could have led to the conclusion that Zostera muelleri was the sole ${ }^{13} \mathrm{C}$-enriched primary producer, which could, in turn, have led to different interpretations of food-web relationships (see Table 1).

The isotopic signatures of primary producers in the present study were similar to values reported previously in a similar habitat of the same region (Leduc et al. 2006). The $\delta^{13} \mathrm{C}$ signature of MPB in June 2005
$(-8.9 \%)$ was more elevated than values reported to date (-9.4 to $-20.6 \%$; see review by Currin et al. 1995). Environmental variables affecting the $\delta^{13} \mathrm{C}$ signature of MPB are not well-understood, although factors such as productivity (Grice et al. 1996), nutrient source (Smit 2001), light condition (Burkhardt et al. 1999), or taxonomic composition (Leboulanger et al. 1995) may be involved. The C:N ratio of some MPB samples (6 to 11) was somewhat higher than the values expected based on the Redfield ratio (6 to 7), perhaps because of the presence of contaminants in some of the samples. The $63 \mu \mathrm{m}$ mesh used for MPB sample processing may not have excluded very small nematodes and copepod nauplii. 
Difficulty in distinguishing MPB from other potential food sources in food-web studies has led some researchers to use nitrogen and sulfur isotopes in addition to carbon. The mean $\delta^{15} \mathrm{~N}$ signatures of primary producers in the present study, however, showed limited variation $(1.4 \%)$. Nitrogen isotopes were therefore of limited use in determining food-web relationships. Sulfur isotopes have been used in several seagrass food-web studies (e.g. Kharlamenko et al. 2001, Leduc et al. 2006), but interpretation of $\delta^{34} \mathrm{~S}$ signatures of infaunal organisms is complicated by the potential for non-dietary sulfur uptake (Leduc et al. 2006).

FA analysis can provide an additional method to trace organic-matter flows in sediments and consumers. Several criteria need to be met, however, for FA biomarkers to be useful in determining consumer diet: (1) potential food sources must contain unique FAs in high abundance, (2) consumers must have no or limited ability to biosynthesize these FAs, and (3) these FAs must be assimilated in significant amounts in consumer tissues when the diet is consumed (Chamberlain et al. 2005). It was not possible to verify whether the latter 2 criteria were met, but the primary producer profiles obtained in the present study can help identify potential biomarkers at the study sites (Table 7).

High levels of $18: 3 \mathrm{n} 3$ are often found in seagrass tissues and this FA is often used as a biomarker in seagrass food-web studies (e.g. Kharlamenko et al. 2001, Jaschinski et al. 2008). Zostera muelleri was indeed found to be rich in 18:3n3 at Papanui Inlet, but cyanobacteria represent another potential source for this FA. Most seagrass tissue is thought to be consumed as detritus (e.g. Danovaro 1996), and the low levels of this FA in detrital $Z$. muelleri also decrease its usefulness as a biomarker. Another FA sometimes used as a biomarker for seagrass, 18:2n6, was found in greater abundance in Enteromorpha sp. than in $Z$. muelleri. Enteromorpha sp. and Ulva sp. were also characterized by high abundance of 18:1n7, a FA common in some green macroalgae (Nelson et al. 2002), but also used as a bacterial biomarker in many foodweb studies (e.g. Meziane \& Tsuchiya 2000). High levels of 20:5n3 (a common diatom biomarker, e.g. Ackman et al. 1968) were found in Polysiphonia sp. and MPB biofilm dominated by dinoflagellates. High abundance of 20:5n3 has previously been recorded from benthic dinoflagellates (Usup et al. 2008) and macroalgae (Graeve et al. 2002). The relatively high abundance of $18: 4 \mathrm{n} 3$ and 18:5n 3 in benthic dinoflagellates, as well as its absence from other primary producers, make these FAs reliable biomarkers for dinoflagellates in Papanui Inlet. The near-absence of 15:0 and 17:0 from all primary producers indicates that these FAs are reliable bacterial biomarkers. The presence of small
Table 7. Fatty acids encountered in the present study that are commonly used as biomarkers in benthic food-web studies, and their sources

\begin{tabular}{|c|c|}
\hline Fatty acid & Common sources \\
\hline$\Sigma 15, \Sigma 17$ & Bacteria $^{1}$, dinoflagellates? ${ }^{3}$ \\
\hline $18: 1 \mathrm{n} 7$ & Bacteria $^{2}$, green macroalgae ${ }^{3,4,5}$ \\
\hline 18:1n9 & Metazoans $^{6,7}$, bacteria $^{8}$, brown macroalgae ${ }^{9}$ \\
\hline 18:2n6 & $\begin{array}{l}\text { Enteromorpha sp. } .^{3,10} \text {, Ulva sp. }{ }^{10} \\
\quad \text { Zostera spp. }{ }^{3,11}, \text { cyanobacteria }^{12}\end{array}$ \\
\hline 18:3n3 & Zostera spp. ${ }^{3,9,11}$, cyanobacteria $^{3,13}$ \\
\hline $18: 4 \mathrm{n} 3$ & $\begin{array}{l}\text { Dinoflagellates }{ }^{1,14} \text {, }^{\text {cryptomonads }}{ }^{14}, \\
\text { cyanobacteria }^{13}\end{array}$ \\
\hline 20:4n6 & Macroalgae $^{4}$, Polysiphonia sp. ${ }^{3}$, protists $^{15,16}$ \\
\hline $20: 5 n 3$ & $\begin{array}{l}\text { Diatoms }{ }^{17}, \text { Polysiphonia sp. }{ }^{3}, \text { dinoflagellates }{ }^{3}, \\
\text { protists }^{18}\end{array}$ \\
\hline 22:6n3 & Dinoflagellates ${ }^{14}$, copepods $^{3,19}$ \\
\hline \multicolumn{2}{|c|}{$\begin{array}{l}{ }^{1} \text { Findlay et al. (1990), }{ }^{2} \text { Volkman et al. (1980), }{ }^{3} \text { the present } \\
\text { study, }{ }^{4} \text { Graeve et al. }(2002),{ }^{5} \text { Nelson et al. (2002), }{ }^{6} \text { Graeve } \\
\text { et al. (1997), }{ }^{7} \text { Nyssen et al. (2005), }{ }^{8} \text { Nichols et al. (1982), } \\
{ }^{9} \text { Alfaro et al. (2006), }{ }^{10} \text { Meziane \& Tsuchiya (2000), }{ }^{11} \text { Khar- } \\
\text { lamenko et al. (2001), }{ }^{12} \text { Caramujo et al. (2008), }{ }^{13} \text { Cook et } \\
\text { al. (2004), }{ }^{14} \text { Sargent et al. (1987), }{ }^{15} \text { Zhukova \& Kharla- } \\
\text { menko (1999), }{ }^{16} \text { Howell et al. (2003), }{ }^{17} \text { Ackman et al. } \\
\text { (1968), }{ }^{18} \text { Veloza et al. (2006), }{ }^{19} \text { Nanton \& Castell (1999) }\end{array}$} \\
\hline
\end{tabular}

amounts of 15:0 in dinoflagellate-dominated biofilm may have been caused by the presence of bacteria in the samples.

\section{SOM}

$\mathrm{SOM} \delta^{13} \mathrm{C}$ signatures at the study sites were relatively enriched in ${ }^{13} \mathrm{C}$ and were similar to Zostera muelleri and MPB signatures. Based on values of $\delta^{13} \mathrm{C}$, the contribution of ${ }^{13} \mathrm{C}$-depleted macroalgae and seston to SOM was likely to be low, although Polysiphonia sp., which had the most ${ }^{13} \mathrm{C}$-enriched macroalgal values in January $2006(-14.7 \%$ ), may have contributed to fine SOM at the densely vegetated site. It appears, therefore, that the degree of benthopelagic coupling at the study sites was limited. A study in a Mediterranean Posidonia oceanica meadow also suggested that seagrass and MPB were important contributors to SOM (Danovaro 1996). In contrast, a stable isotope study in the same region found that the contribution of seston to seagrass-bed SOM is similar to or greater than the contribution of benthic primary producers (Papadimitriou et al. 2005). A compilation of data from the literature led Kennedy et al. (2004) to conclude that seston and epiphytes are generally the main contributors to SOM in seagrass beds. The discrepancy between the latter studies and the present one may reflect a difference in sampling season, habitat (e.g. subtidal vs. intertidal, calcareous vs. siliceous sediments), or seagrass aboveground architecture. Z. muelleri blades, for example, 
are small and may not trap particles as efficiently as Posidonia oceanica blades (but see Heiss et al. 2000). In addition, the input of benthic versus pelagic production to SOM is likely to be greater in intertidal environments. The input of seston to the sediments may also be most pronounced during spring and autumn blooms.

The $\delta^{13} \mathrm{C}$ signatures of SOM at the sparsely vegetated site (bulk and fine fractions) and densely vegetated site (fine fraction only) were more depleted in ${ }^{13} \mathrm{C}$ than Zostera muelleri signatures. ${ }^{13} \mathrm{C}$-depleted sources with lower $\mathrm{C}: \mathrm{N}$ ratios such as MPB could contribute to SOM at those locations. Lower $\delta^{13} \mathrm{C}$ signatures and $\mathrm{C}: \mathrm{N}$ ratios could also be due to greater contribution of Z. muelleri detritus. Seagrass detritus may be depleted by as much as $2 \%$ relative to live material (Fourqurean \& Schrlau 2003), although isotopic shifts associated with the decomposition of seagrass material is usually limited (up to $\sim 1 \%$, Freudenthal et al. 2001). The C:N ratio of vascular plant material decreases during decomposition as associated bacteria incorporate nitrogen from the surrounding environment (Harrison 1989). The similarity between the FA profiles of $Z$. muelleri detritus and SOM at the densely vegetated site, in particular, suggest an important contribution of seagrass detritus to the sediments of that site. The abundance of FAs associated with microalgae (18:4n3, $18: 5 n 3,20: 5 n 3$, and 22:6n3), moreover, was lowest in the fine-SOM fraction at the densely vegetated site where seagrass detritus contribution was greatest according to the FA data.

Macroalgal detritus may also contribute to SOM at the vegetated sites. The FA profile of fine SOM at the densely vegetated site, in particular, could also reflect the presence of macroalgal detritus in addition to seagrass detritus. Little is known about the FA profile of macroalgal detritus, but microbial degradation could lead to decreases in the abundance of common macroalgal biomarkers such as 18:2n6 and 20:4n6 and increases in saturated FAs (Tenore et al. 1984). This could lead to detritus of different origins (e.g. seagrass and macroalgae) having similar FA compositions (Nichols et al. 1982). The presence of macroalgal detritus in ${ }^{13} \mathrm{C}$-depleted fine SOM at the densely vegetated site, therefore, cannot be eliminated.

Ulva sp. and Enteromorpha sp. were identified as potential sources of $18: 1 \mathrm{n} 7$, but the elevated $\delta^{13} \mathrm{C}$ signature of SOM suggests that bacteria are a more likely source of this FA. The sum of bacterial biomarkers was higher in bulk SOM of vegetated (9 to $10 \%$ ) than unvegetated sediments ( $2 \%)$, indicating a greater contribution of detritus within the seagrass bed. Because organic matter content is likely to vary between sites, a more accurate comparison of bacterial contribution to SOM could potentially be obtained by comparing the absolute amounts of FAs instead of relative amounts.

Comparison of FA profiles from bulk and fine SOM can help gain insights into the sources of organic matter to the sediments. The greater abundance of 20:5n3, 22:6n3, and 18:4n3 in fine SOM relative to bulk SOM at the unvegetated site, for example, suggests that they originate from benthic dinoflagellates or other microalgae. On the other hand, the presence of 20:5n3 and 20:4n6 in bulk SOM and their near-absence in fine SOM at the densely vegetated site may reflect the presence of fresh Polysiphonia sp. fragments in the sediments rather than MPB. The significant differences found between bulk and fine SOM FA profiles may also indicate that food sources available to meiofauna (which can only ingest small particles) differ from food sources available to macrofauna.

\section{Nematode diet}

The nematode samples obtained in the present study were composed of several hundred individuals belonging to several ( $>15$ ) species. Modifications in elemental analyzer-isotope ratio mass spectrometry (EA-IRMS) has made possible the analysis of separate species (Carman \& Fry 2002). The nematode communities at the study site, however, consisted primarily of relatively small species (D. Leduc unpubl. data), which made the separation of different taxa difficult. Withinsite variation in $\delta^{13} \mathrm{C}$ signatures between nematode taxa is often limited $(\leq 2 \%$; Carman \& Fry 2002, Moens et al. 2005), although considerable variation was observed in the $\delta^{13} \mathrm{C}$ signatures of nematodes sampled from tropical mangroves (up to $13 \%$; Demopoulos et al. 2007). The results from the present study do not account for the potentially wide variation in diet between the different feeding types (e.g. microbial feeder, deposit feeders, epistrate feeders) likely to have been present in the samples. Values of $\delta^{15} \mathrm{~N}$ can vary considerably, especially when predators are present (3 to 6\%o, Moens et al. 2005). Because variation in primary-producer $\delta^{15} \mathrm{~N}$ signatures was small $(<2 \%)$, differences in nematode $\delta^{15} \mathrm{~N}$ signature are unlikely to change the interpretation of food-web relationships in the present study.

The relative contribution of macrophyte (i.e. seagrass and/or macroalgae) detritus and MPB to the diet of nematodes could not be determined based on stable isotope data due to the overlapping signatures of potential food sources. The $\delta^{13} \mathrm{C}$ and $\delta^{15} \mathrm{~N}$ signature of nematodes, however, closely followed fine SOM signatures at their respective sites. Although little difference was found in the isotopic signature of bulk and fine SOM in unvegetated and sparsely vegetated sediment, the $\delta^{13} \mathrm{C}$ values of nematodes at the densely vegetated 
site more closely resembled fine than bulk SOM signatures. Nematodes may preferentially ingest the smaller components of SOM, at least at the latter site. Seagrass detritus, which is the most likely source of fine SOM at that site (see 'SOM'), may therefore contribute substantially to the diet of nematodes living in densely vegetated areas. Conversely, MPB may be a more likely food source in unvegetated sediments because of the greater contribution of HUFAs (e.g. 18:4n3, 20:5n3, 22:6n3) to fine SOM at that site. Both vascular plant tissue (Couch 1989, Danovaro 1996, Carman \& Fry 2002) and MPB (Moens et al. 2005) may be important food items for nematodes.

\section{Copepod diet}

The elevated $\delta^{13} \mathrm{C}$ signature and high abundance of microalgal FAs in harpacticoid copepods may result from MPB being their main food source in Papanui Inlet, although the lack of seasonal data makes generalizations difficult. The near-absence of dinoflagellate biomarkers (18:4n3 and 18:5n3) suggests that other taxa, such as diatoms, may be more important contributors. The higher variability of copepod isotopic signatures at the densely vegetated site indicates that a greater variety of food sources are ingested when they are available (e.g. small amounts of Zostera muelleri and/or macroalgal detritus). Greater abundance of bacterial FAs in copepods from the same site, moreover, may result from bacteria constituting a more important component of their diet in vegetated sediments. The use of FA composition as an indicator of harpacticoid copepod diet may be problematic due to their ability to biosynthesize significant amounts of HUFAs such as 20:5n3 and 22:6n3 (Nanton \& Castell 1999). The low abundance of other biomarkers such as 18:2n6 and 18:3n3, however, may result from other food sources not being major contributors to the diet of harpacticoid copepods at the study sites (Caramujo et al. 2008). Few data are available on the FA composition of harpacticoid copepods from the field, but the FA profiles obtained for copepods in the present study (which mostly consisted of Parastenhelia megarostrum) are similar to the profile of the harpacticoid copepod Microarthridion littorale from the South Carolina coast (Coull 1999). M. littorale was reported to have a microalgal diet based on isotope labeling experiments and gut pigment analyses (Pace \& Carman 1996).

MPB contributes substantially to the nutrition of harpacticoid copepods in shallow unvegetated sediments (Blanchard 1991, Pace \& Carman 1996). Some researchers, however, have suggested that seston (Vizzini \& Mazzola 2003) and seagrass (Hyndes \& Lav- ery 2005) can contribute significantly to the diet of harpacticoid copepods. The findings of the latter study, however, could be questioned since MPB was poorly represented in the samples (only 1 sample from 1 location was taken across locations separated by several $\mathrm{km})$. The importance of different food sources may depend on their availability. The contribution of seston to meiofaunal diet, for example, may vary depending on the degree of benthopelagic coupling, which is likely to be greater in subtidal meadows vegetated by seagrass species with large above-ground structures than in intertidal beds vegetated by small species such as Zostera muelleri. The contribution of seagrass to secondary production is also likely to depend on the presence of other, more labile food sources such as MPB and macroalgae (Jaschinski et al. 2008).

Parastenhelia megarostrum is the most abundant harpacticoid copepod species in New Zealand shallow sandy sediments and has been shown to be an important food item for juvenile flatfish (Hicks 1984, 1985). P. megarostrum is a high-quality food source (i.e. high in HUFA; Watanabe et al. 1978) and is likely to represent an important link between MPB primary production and higher trophic levels.

The ${ }^{15} \mathrm{~N}$ enrichment of harpacticoid copepods relative to their most likely food source (MPB, $\leq 2.2 \%$ ) was lower than the $3 \%$ enrichment often assumed between consumer and diet (Post 2002), but close to the value reported by McCutchan et al. (2003) for animals analyzed whole $(2.1 \%$ ). McCutchan et al. (2003) also showed that trophic enrichment was lower for primary consumers than for carnivores (approx. 2 vs. $3 \%$ ). Care should therefore be taken when interpreting the diet of meiofaunal organisms based on $\delta^{15} \mathrm{~N}$ signatures, as little experimental evidence is available on their trophic enrichment values.

\section{Feeding experiment}

Some small changes in the FA composition of harpacticoid copepods were observed at the end of the experiment, but there was no significant difference between treatments and controls. These changes are therefore likely to have resulted from the experimental conditions in the microcosms rather than from the addition of Enteromorpha sp. detritus. Furthermore, Enteromorpha sp. detritus (and associated microbiota) did not contribute greatly to their carbon demand $(2 \%)$. The incorporation rate of detritus by copepods in the present study $\left(2.6 \mu \mathrm{g}\right.$ DW $\mathrm{mg} \mathrm{DW}^{-1}{ }_{\text {copepod }} \mathrm{d}^{-1}$ ) was about 10 times smaller than the ingestion rates of the harpacticoid copepod Tisbe cucumariae fed on Gracilaria tikvahiae in short $(1 \mathrm{~h})$ feeding experiments (Guidi 1984). 
The lack of contribution of Enteromorpha sp. detritus to the copepod diet in the present study is somewhat surprising because macroalgae are considered a highquality food source (Tenore et al. 1984). Extending the experiment possibly could have allowed greater decomposition of Enteromorpha sp. detritus by bacteria and increased its palatability to consumers. Rich bacterial growth associated with Enteromorpha sp. fragments was observed on Day 4 of the experiment, however, suggesting that Enteromorpha sp. was available to consumers in the form of detritus and associated microbiota for several days. Harpacticoid copepods appear to have fed on MPB preferentially in the feeding experiment, supporting the field data. However, a concurrent experiment using labeled MPB would have been useful to confirm this observation. These findings agree with several studies that have highlighted the importance of MPB in the nutrition of harpacticoid copepods (e.g. Blanchard 1991, Montagna et al. 1995, Pace \& Carman 1996).

\section{Combining isotopic and FA biomarker approaches}

The use of stable isotopes and FA biomarker approaches in food-web studies is more powerful than either method in isolation (e.g. Alfaro et al. 2006, Jaschinski et al. 2008). In the present study, however, the isotopic signatures of some primary producers overlapped, and the use of FA biomarkers was hampered by their presence in $>1$ primary producer. The isotopic signature of SOM, nematodes, and harpacticoid copepods did not vary greatly between adjoining sites at Papanui Inlet. There were, however, significant differences in the FA composition of SOM between sites and size fractions. The effectiveness of FAs in tracing seagrass detritus in the sediments was improved by the analysis of aged detritus and the use of multivariate statistics (as opposed to the use of specific biomarkers). In addition, significant differences in the FA profiles of harpacticoid copepods occurred between sites despite the lack of differences in their $\delta^{13} \mathrm{C}$ signatures. The feeding experiment provided support for the importance of MPB to the diet of harpacticoid copepods in unvegetated sediments. Nematode diet could not be determined with certainty due to the overlapping isotopic signatures of primary producers.

The use of several approaches in the present study did not give adequate quantitative estimates of primary producer contribution to the diet of harpacticoid copepods and nematodes. The qualitative nature of FA analysis, in particular, is limiting. Comparing the FA profile of animals fed a diet of known FA composition with that of individuals from the field could help deter- mine their diet with more accuracy (Ruess et al. 2005). Microcosm and field experiments using a range of isotopically labeled food sources (e.g. macroalgae, seagrass, MPB) could also help quantify the relative importance of primary producers to the diet of meiofaunal organisms (Middelburg et al. 2000).

The use of FA analysis in the present study was limited to harpacticoid copepods due to their relatively large size and ease of extraction. The need for relatively large ( 1 mg DW) samples limits the widespread application of FA analyses for the study of meiofaunal trophic connections. Improvements on current methods may, however, make the study of meiofaunal feeding relationships easier in the future (Akoto et al. 2008).

Acknowledgements. This study was funded by a University of Otago Postgraduate Scholarship and by the Department of Marine Science, University of Otago. We thank B. Dickson, D. Wilson, K. Bonney, and K. Neal for their technical assistance.

\section{LITERATURE CITED}

Ackman RG, Tocher CS, McLachlan J (1968) Marine phytoplankter fatty acids. J Fish Res Board Can 25:1603-1620

Akoto L, Stellaard F, Irth H, Vreuls RJ, Pel R (2008) Improved fatty acid detection in micro-algae and aquatic meiofauna species using a direct thermal desorption interface combined with comprehensive gas chromatography-time-offlight mass spectrometry. J Chromatogr A 1186:254-261

Albrecht N, Vennell R (2007) Tides in two constricted New Zealand lagoons. N Z J Mar Freshw Res 41:103-118

Alfaro CA, Thomas FIM, Sergent L, Duxbury M (2006) Identification of trophic interactions within an estuarine food web (northern New Zealand) using fatty acid biomarkers and stable isotopes. Estuar Coast Shelf Sci 70:271-286

Blanchard GF (1991) Measurement of meiofauna grazing rates on microphytobenthos: is primary production a limiting factor? J Exp Mar Biol Ecol 147:37-46

Bligh EG, Dyer WJ (1959) A rapid method of total lipid extraction and purification. Can J Biochem Cell Biol 37:911-917

Boschker HTS, Wielemaker A, Schaub BEM, Holmer M (2000) Limited coupling of macrophyte production and bacterial carbon cycling in the sediments of Zostera spp. meadows. Mar Ecol Prog Ser 203:181-189

Burkhardt S, Riebesell U, Zondervan I (1999) Stable carbon isotope fractionation by marine phytoplankton in response to daylength, growth rate, and $\mathrm{CO}_{2}$ availability. Mar Ecol Prog Ser 184:31-41

Caramujo MJ, Boschker HTS, Admiraal W (2008) Fatty acid profiles of algae mark the development and composition of harpacticoid copepods. Freshw Biol 53:77-90

Carman KR, Fry B (2002) Small-sample methods for $\delta^{13} \mathrm{C}$ and $\delta^{15} \mathrm{~N}$ analysis of the diets of marsh meiofaunal species using natural-abundance and tracer-addition isotope techniques. Mar Ecol Prog Ser 240:85-92

> Chamberlain PM, Bull ID, Black HIJ, Ineson P, Evershed RP (2005) Fatty acid composition and change in Collembola fed differing diets: identification of trophic biomarkers. Soil Biol Biochem 37:1608-1624 
Clarke KR, Gorley RN (2006) PRIMER v6: user manual/tutorial. PRIMER-E, Plymouth

Cook PLM, Revill AT, Clementson LA, Volkman JK (2004) Carbon and nitrogen cycling on intertidal mudflats of a temperate Australian estuary. III. Sources of organic matter. Mar Ecol Prog Ser 280:55-72

$>$ Couch CA (1989) Carbon and nitrogen stable isotopes of meiobenthos and their food resources. Estuar Coast Shelf Sci 28:433-441

Coull BC (1999) Role of meiofauna in estuarine soft-bottom habitats. Aust J Ecol 24:327-343

> Currin CA, Newell SY, Paerl HW (1995) The role of standing dead Spartina alterniflora and benthic microalgae in saltmarsh food webs: considerations based on multiple stable isotope analysis. Mar Ecol Prog Ser 121:99-116

$>$ Danovaro R (1996) Detritus-bacteria-meiofauna interactions in a seagrass bed (Posidonia oceanica) of the NW Mediterranean. Mar Biol 127:1-13

> Danovaro R, Gambi C, Mirto S (2002) Meiofaunal production and energy transfer efficiency in a seagrass Posidonia oceanica bed in the western Mediterranean. Mar Ecol Prog Ser 234:95-104

> Demopoulos AWJ, Fry B, Smith CR (2007) Food web in exotic and native mangroves: a Hawaii-Puerto Rico comparison. Oecologia 153:675-686

Findlay RH, Trexler MB, Guckert JB, White DC (1990) Laboratory study of disturbance in marine sediments response of a microbial community. Mar Ecol Prog Ser 62: 121-133

Fourqurean JW, Schrlau JE (2003) Changes in nutrient content and stable isotope ratios of $\mathrm{C}$ and $\mathrm{N}$ during decomposition of seagrasses and mangrove leaves along a nutrient availability gradient in Florida Bay, USA. Chem Ecol 19: 373-390

Freudenthal T, Wagner T, Wenzhofer F, Zabel M, Wefer G (2001) Early diagenesis of organic matter from sediments of the eastern subtropical Atlantic: evidence from stable nitrogen and carbon isotopes. Geochim Cosmochim Acta 65:1795-1808

Fry B (2006) Stable isotope ecology. Springer, New York

> Graeve M, Kattner G, Piepenburg D (1997) Lipids in Arctic benthos: Does the fatty acid and alcohol composition reflect feeding and trophic interactions? Polar Biol 18: 53-61

> Graeve M, Kattner G, Wiencke C, Karsten U (2002) Fatty acid composition of Arctic and Antarctic macroalgae: indicator of phylogenetic and trophic relationships. Mar Ecol Prog Ser 231:67-74

Grice AM, Loneragan NR, Dennison WC (1996) Light intensity and the interactions between physiology, morphology and stable isotope ratios in five species of seagrass. J Exp Mar Biol Ecol 195:91-110

> Grove SL, Probert PK, Berkenbusch K, Nodder SD (2006) Distribution of bathyal meiofauna in the region of the Subtropical Front, Chatham Rise, south-west Pacific. J Exp Mar Biol Ecol 330:342-355

> Guidi LD (1984) The effect of food composition on ingestion, development, and survival of a harpacticoid copepod, Tisbe cucumariae Humes. J Exp Mar Biol Ecol 84: 101-110

Harrison PG (1989) Detrital processing in seagrass systems: a review of factors affecting decay rates, remineralization and detritivory. Aquat Bot 35:263-288

Hedges JI, Stern JH (1984) Carbon and nitrogen determinations of carbonate-containing solids. Limnol Oceanogr 29: 657-663

Heip C, Vincx M, Vranken G (1985) The ecology of marine nematodes. Oceanogr Mar Biol 23:399-489
Heiss WM, Smith AM, Probert PK (2000) Influence of the small intertidal seagrass Zostera novazelandica on linear water flow and sediment texture. N Z J Mar Freshw Res 34:689-694

> Hemminga MA, Mateo MA (1996) Stable carbon isotopes in seagrasses: variability in ratios and use in ecological studies. Mar Ecol Prog Ser 140:285-298

Hicks GRF (1984) Spatio-temporal dynamics of a meiobenthic copepod and the impact of predation-disturbance. J Exp Mar Biol Ecol 81:47-72

Hicks GRF (1985) Biomass and production estimates for an estuarine meiobenthic copepod, with an instantaneous assessment of exploitation by flatfish predators. N Z J Ecol 8:125-127

> Howell KL, Pond DW, Billett DSM, Tyler PA (2003) Feeding ecology of deep-sea seastars (Echinodermata: Asteroidea): a fatty-acid biomarker approach. Mar Ecol Prog Ser 255: 193-206

Hyndes GA, Lavery PS (2005) Does transported seagrass provide an important trophic link in unvegetated, nearshore areas? Estuar Coast Shelf Sci 63:633-643

> Jaschinski S, Brepohl DC, Sommer U (2008) Carbon sources and trophic structure in an eelgrass Zostera marina bed, based on stable isotope and fatty acid analyses. Mar Ecol Prog Ser 358:103-114

Kanazawa A, Teshima S, Ono K, Chalayondeja K (1979) Biosynthesis of fatty acids from acetate in prawns Penaeus monodon and Penaeus merguiensis. Kagoshima University Report, Kagoshima

Kennedy H, Gacia E, Kennedy DP, Papadimitriou S, Duarte CM (2004) Organic carbon sources to SE Asian coastal sediments. Estuar Coast Shelf Sci 60:59-68

Kharlamenko VI, Kiyashko SI, Imbs AB, Vyshkvartzev DI (2001) Identification of food sources of invertebrates from the seagrass Zostera marina community using carbon and sulfur stable isotope ratio and fatty acid analyses. Mar Ecol Prog Ser 220:103-117

Kuipers BR, Dewilde P, Creutzberg F (1981) Energy flow in a tidal flat ecosystem. Mar Ecol Prog Ser 5:215-221

> Leboulanger C, Descolasgros C, Fontugne MR, Bentaleb I, Jupin H (1995) Interspecific variability and environmental influence on particulate organic carbon $\delta^{13} \mathrm{C}$ in cultured marine phytoplankton. J Plankton Res 17: 2079-2091

Leduc D (2009) Description of Oncholaimus moanae sp. nov. (Nematoda: Oncholaimidae), with notes on feeding ecology based on isotopic and fatty acid composition. J Mar Biol Assoc UK 89:337-344

Leduc D, Probert PK, Frew RD, Hurd CL (2006) Macroinvertebrate diet in intertidal seagrass and sandflat communities: a study using C, N, and S stable isotopes. N Z J Mar Freshw Res 40:615-629

> Lepoint G, Dauby P, Gobert S (2004) Applications of C and N stable isotopes to ecological and environmental studies in seagrass ecosystems. Mar Pollut Bull 49:887-891

> McCutchan JH, Lewis WM, Kendall C, McGrath CC (2003) Variation in trophic shift for stable isotope ratios of carbon, nitrogen, and sulfur. Oikos 102:378-390

Meziane T, Tsuchiya M (2000) Fatty acids as tracers of organic matter in the sediment and food web of a mangrove/intertidal flat ecosystem, Okinawa, Japan. Mar Ecol Prog Ser 200:49-57

Middelburg JJ, Barranguet C, Boschker HTS, Herman PMJ, Moens T, Heip CHR (2000) The fate of intertidal microphytobenthos carbon: an in-situ $\delta^{13} \mathrm{C}$-labelling study. Limnol Oceanogr 45:1224-1234

Moens T, Vincx M (1997) Observations on the feeding ecology of estuarine nematodes. J Mar Biol Assoc UK 77: 211-227 
Moens T, Luyten C, Middleburg JJ, Herman PMJ, Vincx M (2002) Tracing organic matter sources of estuarine tidal flat nematodes with stable carbon isotopes. Mar Ecol Prog Ser 234:127-137

Moens T, Bouillon S, Gallucci F (2005) Dual stable isotope abundances unravel trophic position of estuarine nematodes. J Mar Biol Assoc UK 85:1401-1407

- Moens T, Vanhove S, De Mesel I, Kelemen B, Janssens T, Dewicke A, Vanreusel A (2007) Carbon sources of Antarctic nematodes as revealed by natural carbon isotope ratios and a pulse-chase experiment. Polar Biol 31:1-13

Montagna PA, Blanchard GF, Dinet A (1995) Effect of production and biomass of intertidal microphytobenthos on meiofaunal grazing rates. J Exp Mar Biol Ecol 185:149-165

Mutchler T, Sullivan MJ, Fry B (2004) Potential of ${ }^{14} \mathrm{~N}$ isotope enrichment to resolve ambiguities in coastal trophic relationships. Mar Ecol Prog Ser 266:27-33

Nanton DA, Castell JD (1999) The effects of temperature and dietary fatty acids on the fatty acid composition of harpacticoid copepods, for use as a live food for marine fish larvae. Aquaculture 175:167-181

Nelson MM, Phleger CF, Nichols PD (2002) Seasonal lipid composition in macroalgae of the northeastern Pacific Ocean. Bot Mar 45:58-65

Nichols PD, Klumpp DW, Johns RB (1982) Study of food-chains in seagrass communities 1. Lipid components of the seagrasses Posidonia australis and Heterozostera tasmanica as indicators of carbon source. Phytochemistry 21: 1613-1621

> Nyssen F, Brey T, Dauby P, Graeve M (2005) Trophic position of Antarctic amphipods - enhanced analysis by a 2-dimensional biomarker assay. Mar Ecol Prog Ser 300:135-145

Pace MC, Carman KR (1996) Interspecific differences among meiobenthic copepods in the use of microalgal food resources. Mar Ecol Prog Ser 143:77-86

Papadimitriou S, Kennedy H, Kennedy DP, Duarte CM, Marba N (2005) Sources of organic matter in seagrass-colonized sediments: a stable isotope study of the silt and clay fraction from Posidonia oceanica meadows in the western Mediterranean. Org Geochem 36:949-961

Parrish CC, Abrajano TA, Budge SM, Helleur RJ, Hudson ED, Pulchan K, Ramos C (2000) Lipid and phenolic biomarkers in marine ecosystems: analysis and applications. In: Wangersky P (ed) The handbook of environmental chemistry. Springer, Berlin, p 193-233

Pernet F, Gauthier-Clerc S, Mayrand E (2007) Change in lipid composition in eastern oyster (Crassostrea virginica Gmelin) exposed to constant or fluctuating temperature regimes. Comp Biochem Physiol B 147:557-565

Post DM (2002) Using stable isotopes to estimate trophic position: models, methods, and assumptions. Ecology 83: 703-718

Romeyn K, Bouwman LA (1983) Food selection and consumption by estuarine nematodes. Hydrobiol Bull 17:103-109

Rossi F (2007) Recycle of buried macroalgal detritus in sediments: use of dual-labelling experiments in the field. Mar Biol 150:1073-1081

Editorial responsibility: Robert Feller,

Columbia, South Carolina, USA
Ruess L, Schutz K, Haubert D, Haggblom MM, Kandeler E, Scheu S (2005) Application of lipid analysis to understand trophic interactions in soil. Ecology 86:2075-2082

Sargent JR, Parkes RJ, Mueller-Harvey I, Henderson RJ (1987) Lipids biomarkers in marine ecology. In: Sleigh M (ed) Microbes in the sea. Ellis Horwood, Chichester, p 119-138

Smit AJ (2001) Source identification in marine ecosystems. In: Unkovich M, Pate J, McNeill A, Gibbs DJ (eds) Stable isotope techniques in the study of biological processes and functioning of ecosystems, Vol 40. Kluwer Academic Publishers, Dordrecht, p 219-245

Somerfield PJ, Warwick RM (1996) Meiofauna in marine pollution monitoring programmes: a laboratory manual. Ministry of Agriculture, Fisheries and Food, Lowestoft

Tenore KR, Tietjen JH, Lee JJ (1977) Effect of meiofauna on incorporation of aged eelgrass, Zostera marina, detritus by polychaete Nephthys incisa. J Fish Res Board Can 34: 563-567

Tenore KR, Cammen L, Findlay SEG, Phillips N (1982) Perspectives of research on detritus - Do factors controlling the availability of detritus to macroconsumers depend on its source? J Mar Res 40:473-490

Tenore KR, Hanson RB, McClain J, Maccubbin AE, Hodson R (1984) Changes in composition and nutritional values to a benthic deposit feeder of decomposing detritus pools. Bull Mar Sci 35:299-311

Usup G, Hamid SZ, Chiet PK, Wah CK, Ahmad A (2008) Marked differences in fatty acid profiles of some planktonic and benthic marine dinoflagellates from Malaysian waters. Phycologia 47:105-111

Veloza AJ, Chu FL, Tang KW (2006) Trophic modification of essential fatty acids by heterotrophic protists and its effects on the fatty acid composition of the copepod Acartia tonsa. Mar Biol 148:779-788

Vizzini S, Mazzola A (2003) Seasonal variations in the stable carbon and nitrogen isotope ratios $\left({ }^{13} \mathrm{C} /{ }^{12} \mathrm{C}\right.$ and $\left.{ }^{15} \mathrm{~N} /{ }^{14} \mathrm{~N}\right)$ of primary producers and consumers in a western Mediterranean coastal lagoon. Mar Biol 142:1009-1018

Volkman JK, Johns RB, Gillan FT, Perry GJ, Bavor HJ (1980) Microbial lipids of an intertidal sediment-I. Fatty acids and hydrocarbons. Geochim Cosmochim Acta 44: 1133-1143

Watanabe T, Arakawa T, Kitajima C, Fukusho K, Fujita S (1978) Nutritional quality of living feed from the viewpoint of essential fatty acids for fish. Bull Jpn Soc Sci Fish 44: $1223-1227$

Wells JBJ, Hicks GRF, Coull BC (1982) Common harpacticoid copepods from New Zealand harbours and estuaries. N Z J Zool 9:151-184

Wieser W (1953) Die Beziehung zwischen Mundhohlengestalt, Ernahrungsweise und Vorkommen bei freilebenden marinen Nematoden. Arkiv Zool 2:439-484

Zhukova NV, Kharlamenko VI (1999) Sources of essential fatty acids in the marine microbial loop. Aquat Microb Ecol 17:153-157

Submitted: December 15, 2008; Accepted: February 25, 2009 Proofs received from author(s): May 10, 2009 